University of Louisville

ThinkIR: The University of Louisville's Institutional Repository

1932

\title{
The effect of alcohol on the bodies of guinea pigs with special reference to the thyroid gland.
}

\author{
A. F. Stoner \\ University of Louisville
}

Follow this and additional works at: https://ir.library.louisville.edu/etd

Part of the Chemicals and Drugs Commons

\section{Recommended Citation}

Stoner, A. F., "The effect of alcohol on the bodies of guinea pigs with special reference to the thyroid gland." (1932). Electronic Theses and Dissertations. Paper 1964.

https://doi.org/10.18297/etd/1964

This Master's Thesis is brought to you for free and open access by ThinkIR: The University of Louisville's Institutional Repository. It has been accepted for inclusion in Electronic Theses and Dissertations by an authorized administrator of ThinkIR: The University of Louisville's Institutional Repository. This title appears here courtesy of the author, who has retained all other copyrights. For more information, please contact thinkir@louisville.edu. 
OYIVERSITY OF LOUISVIITS

THE EFFECT OF AICOHOL ON THE BODTES OF GOTIEA

PIOS VITH SPECIAL REIPEREMCE TO TFE TEXROID GLAND.

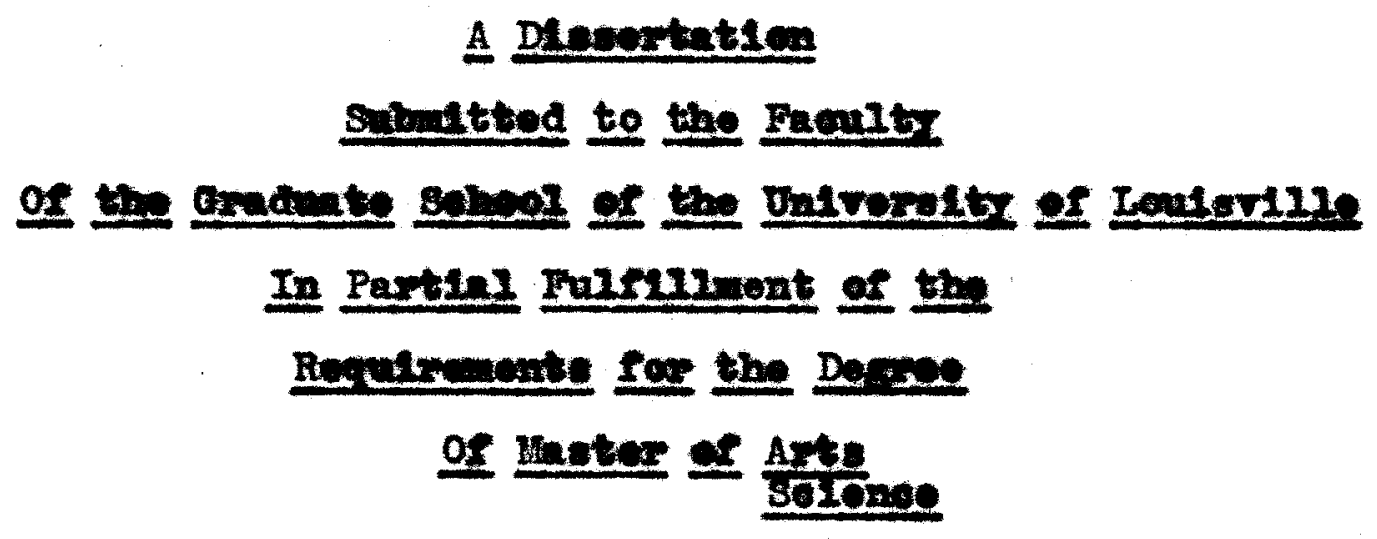

Department of Blole.t

bx

A. F. STOMTR $\checkmark$

1932 
DEDICATIOU

Hs Mighost approelatien and doppot

gratitude are dvo Dr. Anotin RaIph

Middioter of the Dopartiont a Buars

of the Oniveralty of Loularille for

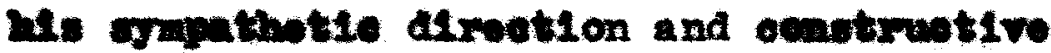
orticion of this atuas. 
CONTHETS

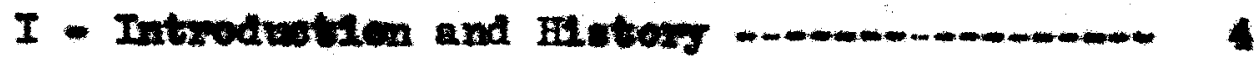

II - Groes Experimental stred on the

Guinoe PlEs

(A) - Notorial and wothod ror the

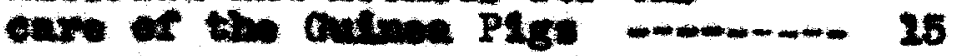

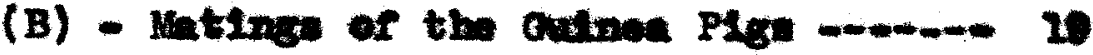

(c) - Gonotril Effoeti of Alechar

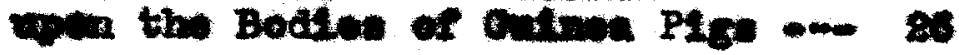

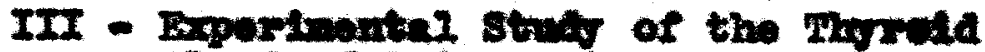
Gland of Calinoa PIg:

(A) - Interial and Mothoda fo.

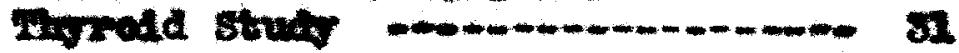

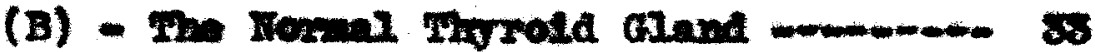

(c) - The Alecholsued Trorotd aland - 38

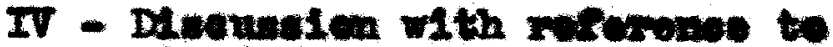

Clted Litontwe -

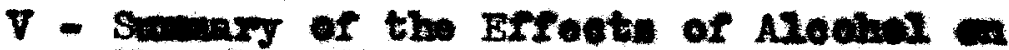

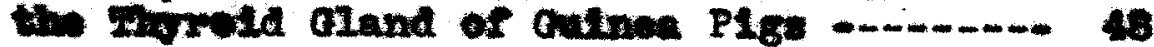

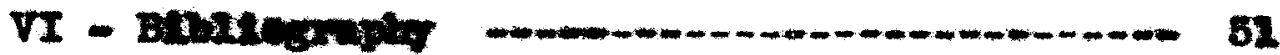


I

8

88

INTRODJCTION AND EISTOFI

เ 1

3 
The reeont diseciveries in the rlela of ondeorinoles has lod to extenelve study in the pharmeelegienl

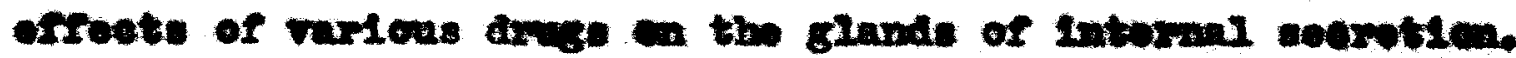

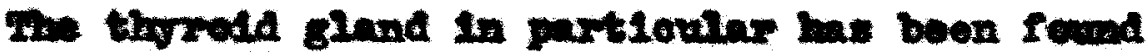
to obange Its struoture and apparranes mon cortaln drage aro aduinistored to experimontel andmale.

As fax as I have been able to obsorve, thore has beon no inrestigatien of a morevenple nature of the -rreet of aleobs upon the thomeld gland. It was, thorefore. doslend to atudy this problen and to make some sonoral observations of the arfoct of aleohel upen the gxomth and porognang of gutina plgs.

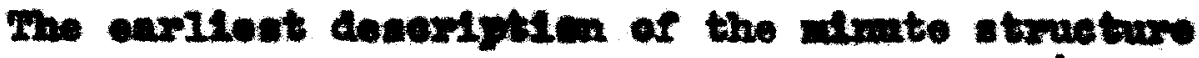
of the normal thy old gland is that of Iangendorer (10).

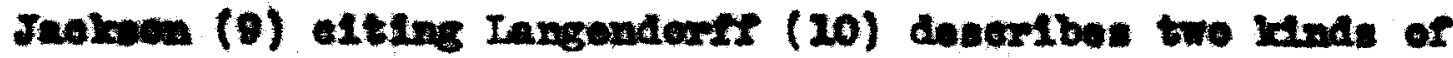

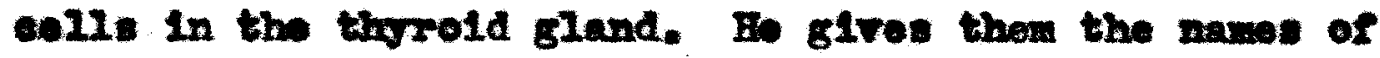
privelpal colls and colleld colls. Fo found the prinolpal

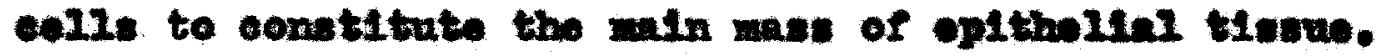

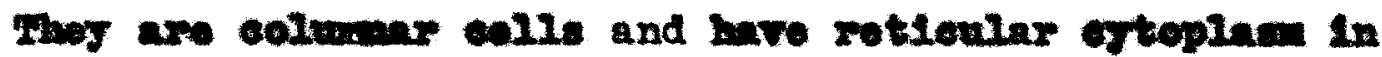

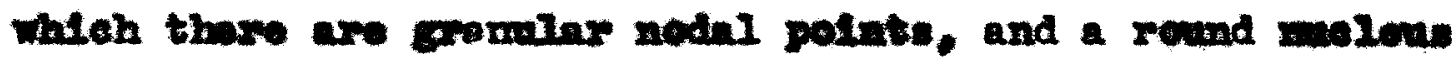
at the bacal ond of eaoh cell. Ho foumd the calletd colls

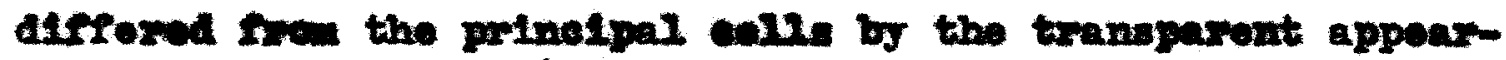

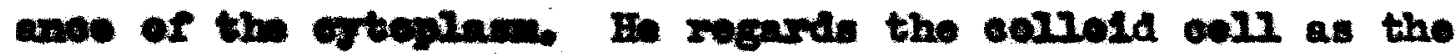
colls ongaged in secusting oollold, bat did not const hinself deringtely to the opinion that they alght roturn to the stato of the prinolpal coll.

Citing Rabollo and Da Coota (25) Jaokeon (9)

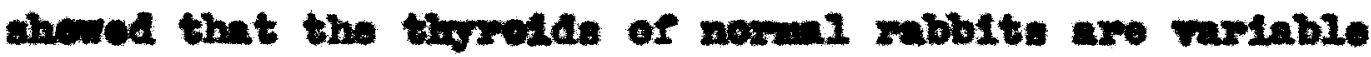




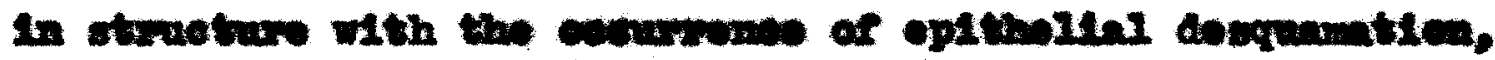

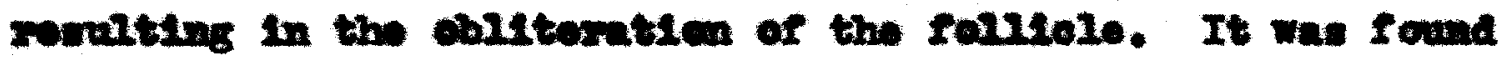
that by injoeting rabbits with thyrold probeld extracts this degenonatien alght be hatronod.

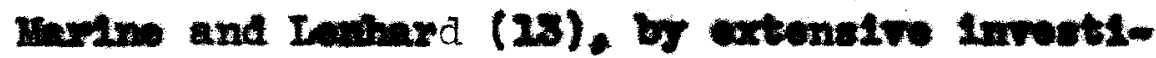

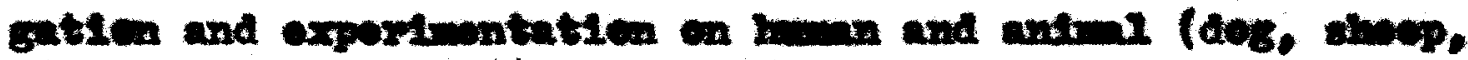

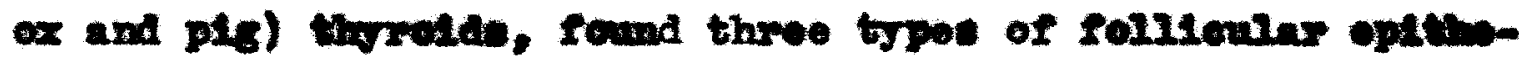
Lan earles

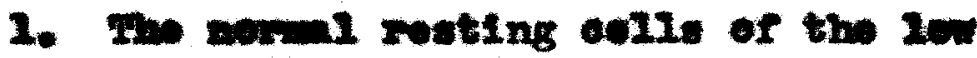
asment byes

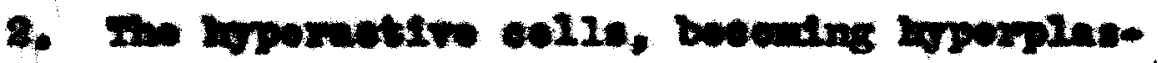

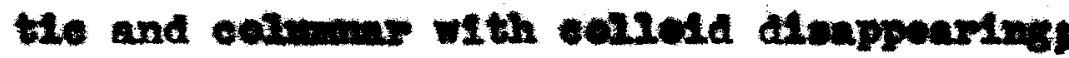

3. Colls of the collede atage (otage of ro-

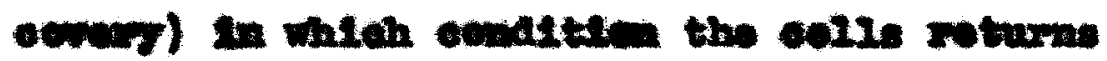

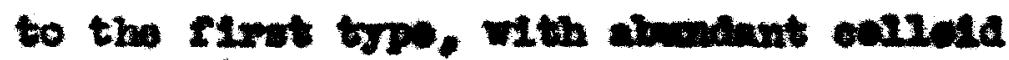
mberlal. If the kpounctive stage contimos

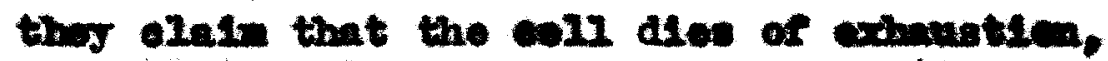

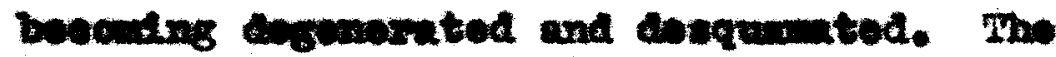

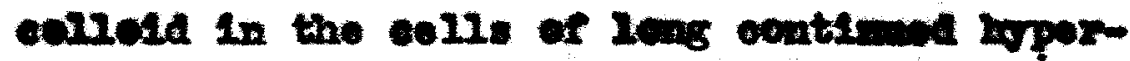
activity wll have ooplotely dieapionrod.

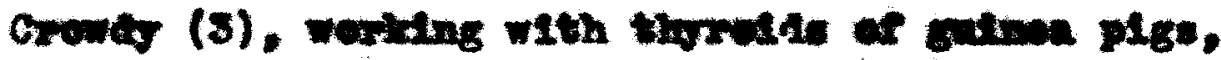

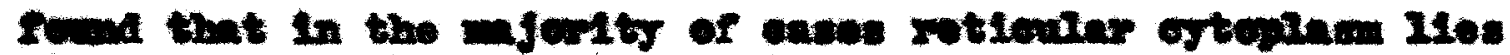

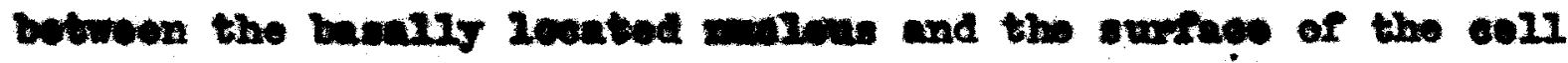

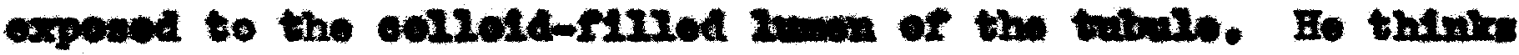

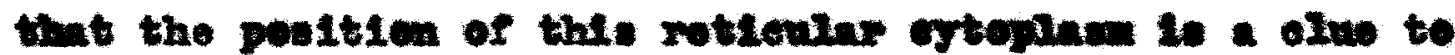
the direotien of soerviten. The small pereontages of rover-

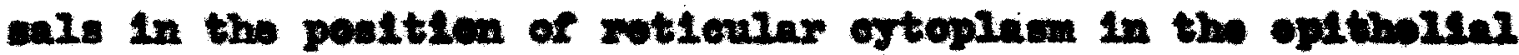

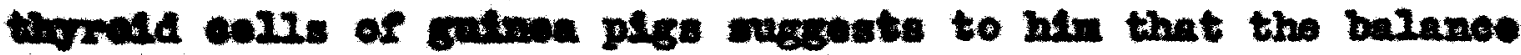


in preducties of soorotien is in favor of atouge rather than Inodinte disehargo.

Inoken (9) round that in albsm sate thow

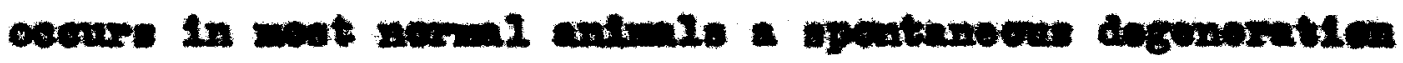
or the secroting collold colls and eolield abbtenoes or the gland.

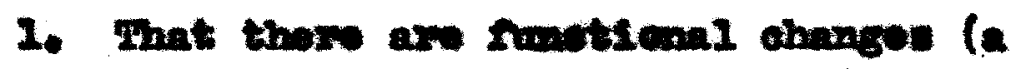
ahange swan the reating conditsen to the uparaetive conditien, and then to the cerbud ecmatticals

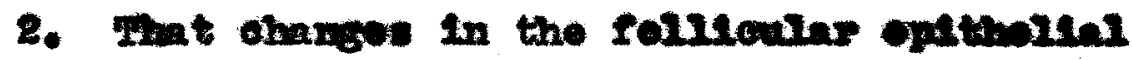

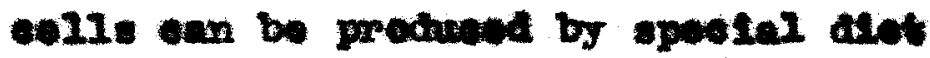

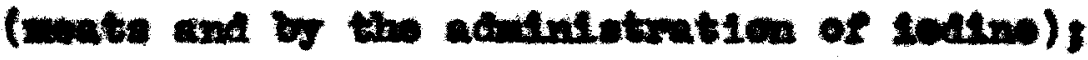

8. That tacte vabotanoes (protold extsobve)

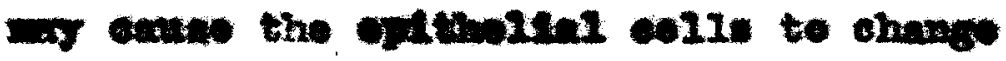

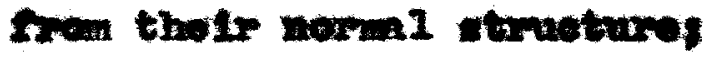

4. Wet with age thore is a tondanor for

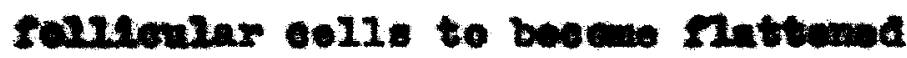
(andie atrughe olanos).

Benaley (2) anwe the origtin of the inturu

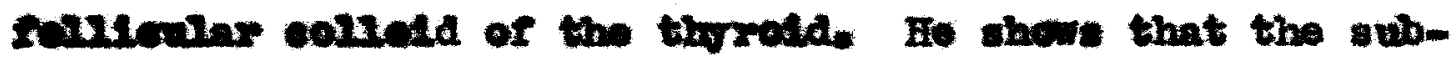

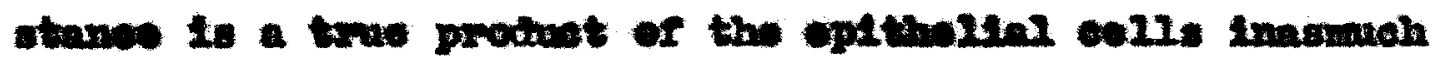

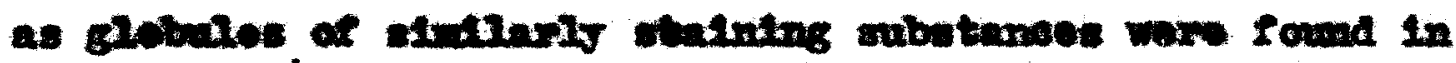

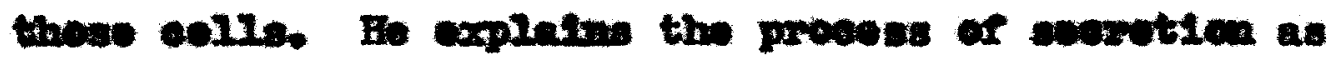
rallowes

$$
\begin{aligned}
& \text { 1. Twe folltevine opthollal colls of the }
\end{aligned}
$$

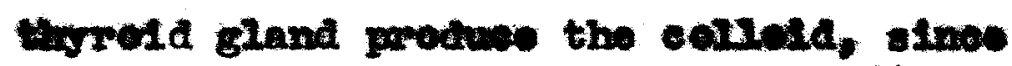

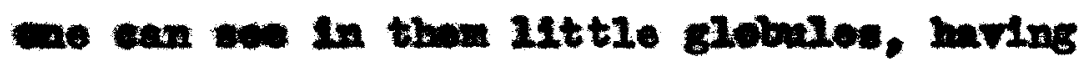




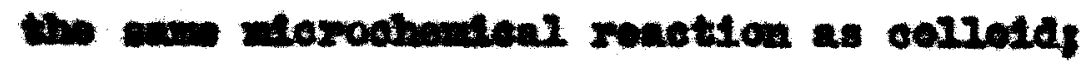

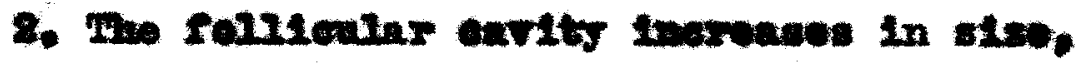

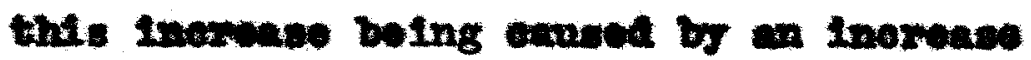
in the eavity and alwo by an increace in the andet of colleda maring in its

3. Afver the vovel is riled, its ocutents

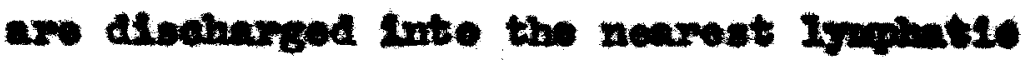
weesely

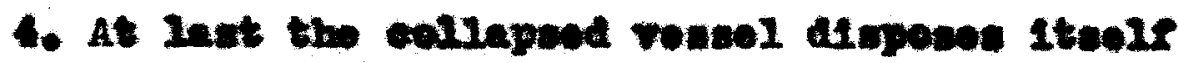
in the fore of 14ttle anint whioh ropont tho prosues.

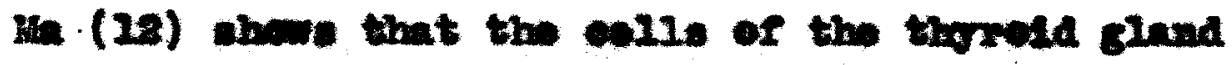

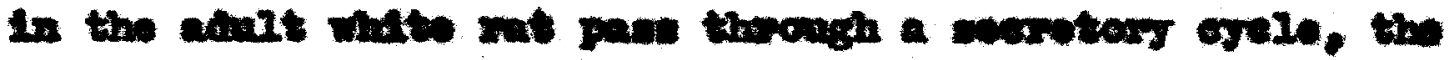

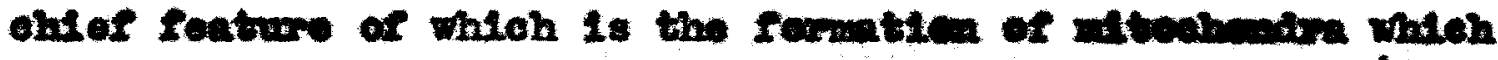

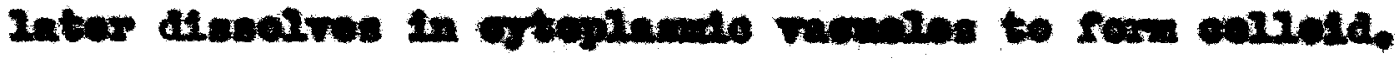

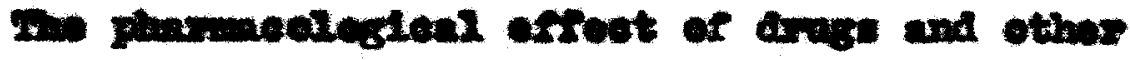

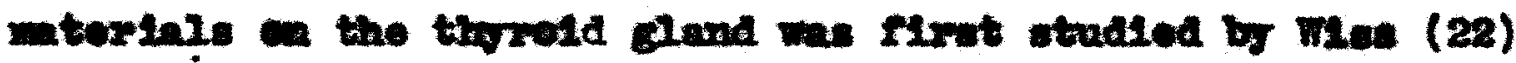

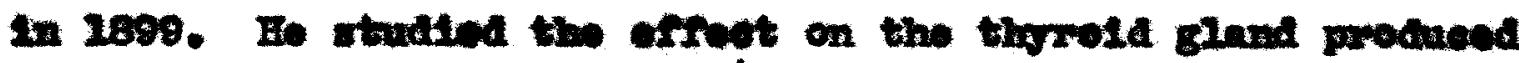

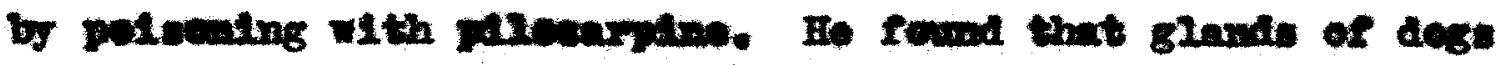

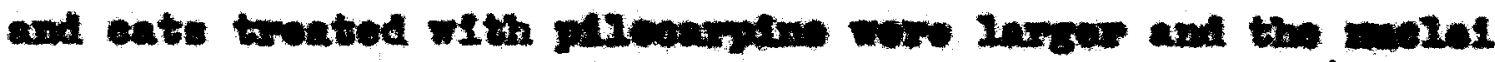

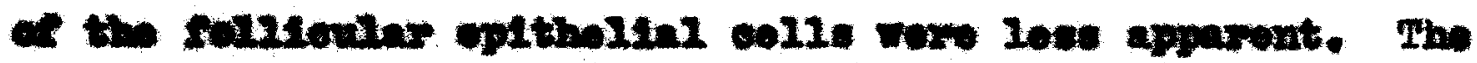
trov onde of the eella were proienged into provesest which

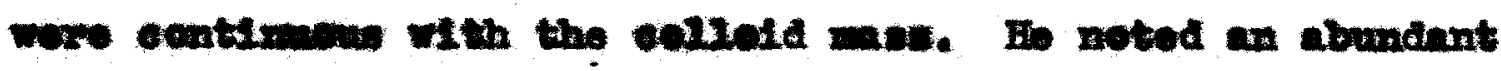
(abmorenl) blewa mplis.

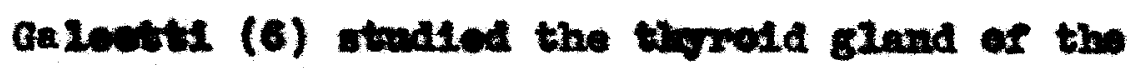

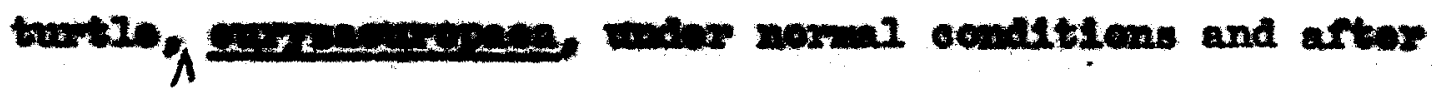

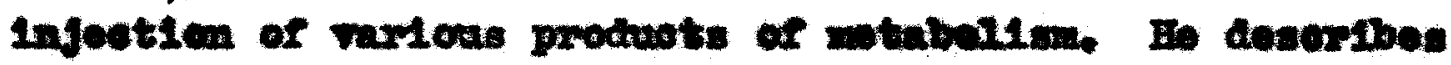


two Ind of segrotions from the colletd cells:

1. Funatiophiste gramiles of molear origlng

8. Droplets of collold.

Bunt and soldex (7) in axperiments en the efreot of thyrold axtraet upen the realetanes or andmis to

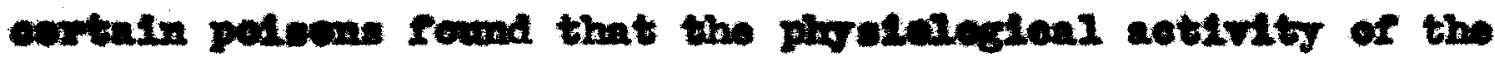
thoreld dopende ween ite ledine oentent.

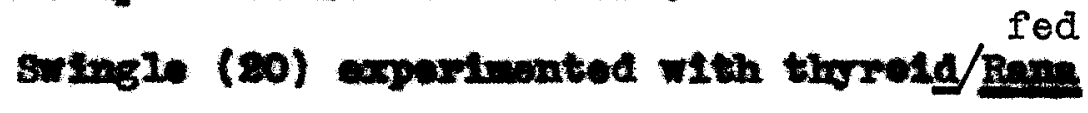

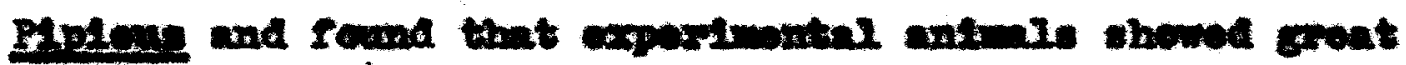

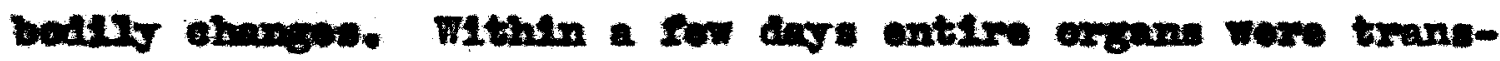

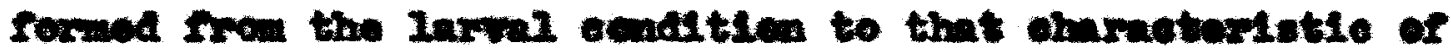

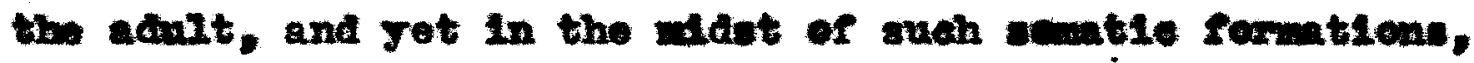

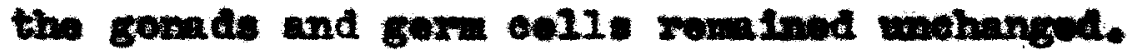

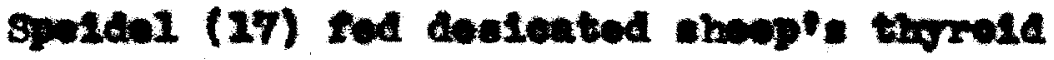

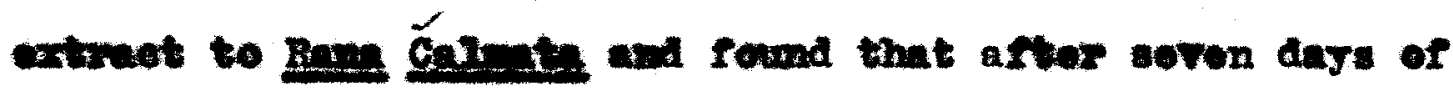

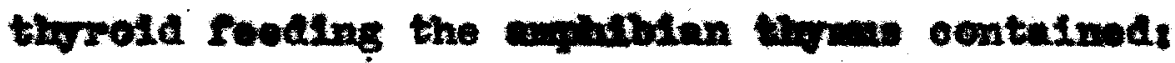

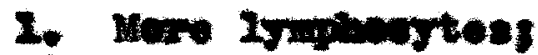

8. That the sine of 1ts bleod almove wore devereand,

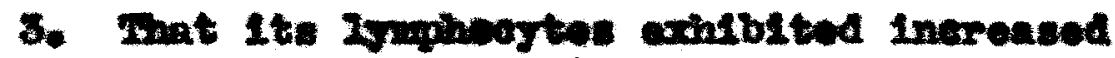
nigratery actirits.

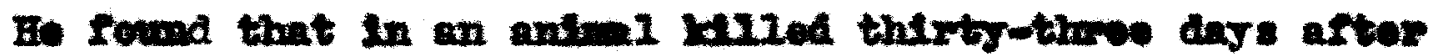

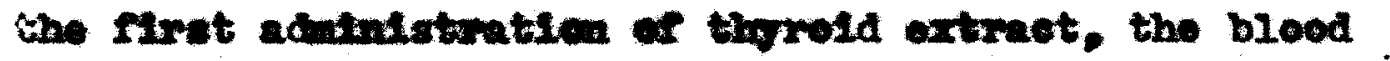

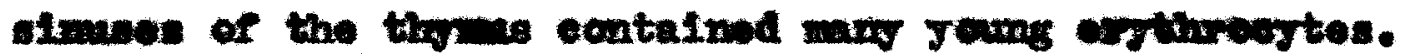
Ho concluded that this was che to the lyperastivity or

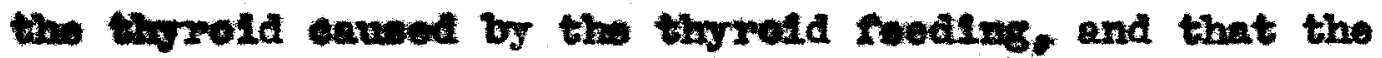

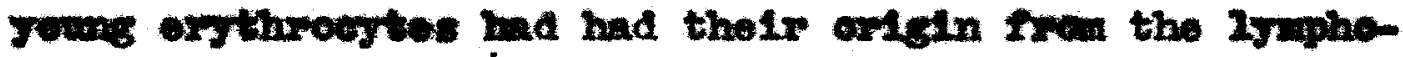
egtes of the thruas. 


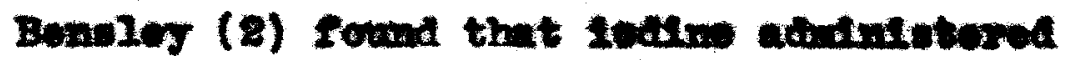

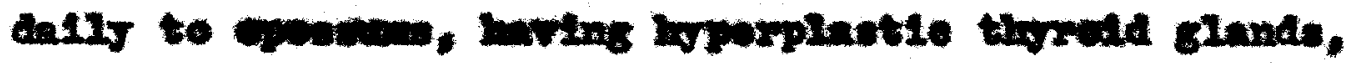

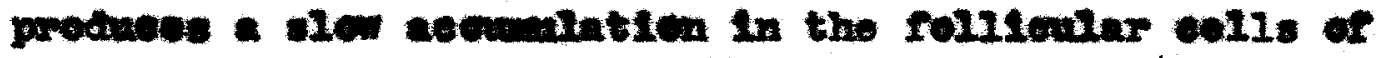

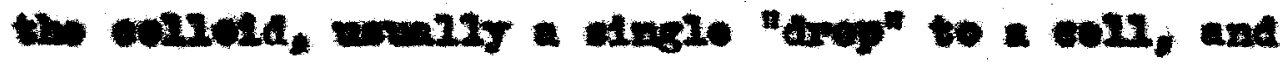

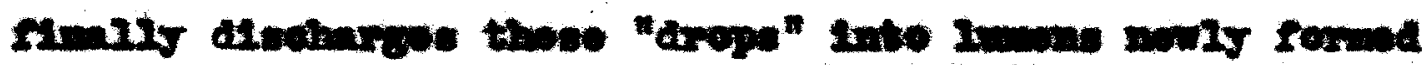

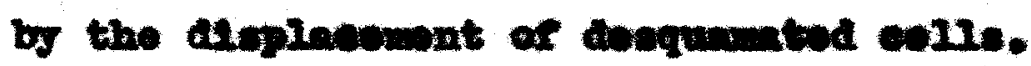

Watsen (m) and Beneis (8) have noted the

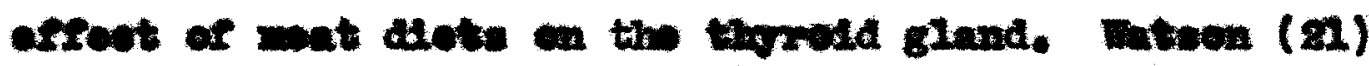

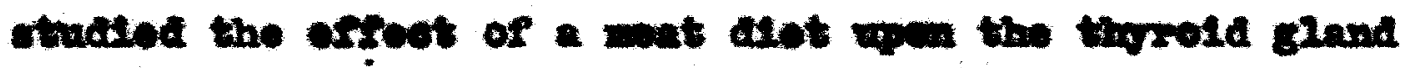

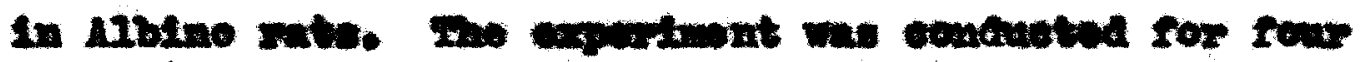

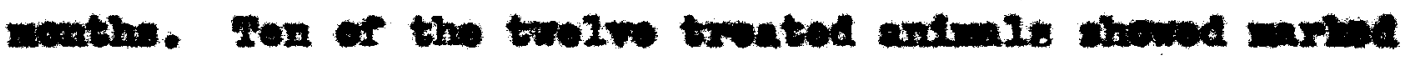

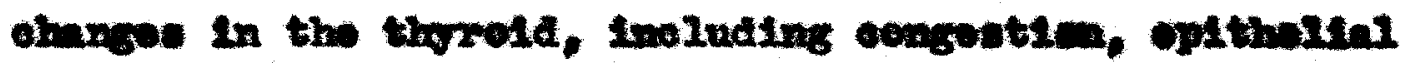

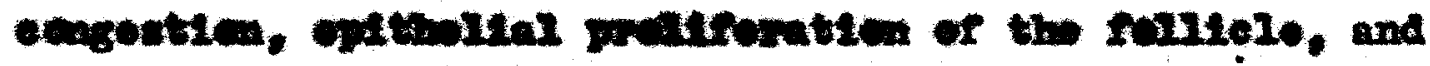
anevare in tho wnent of colletd in the folltele. In a

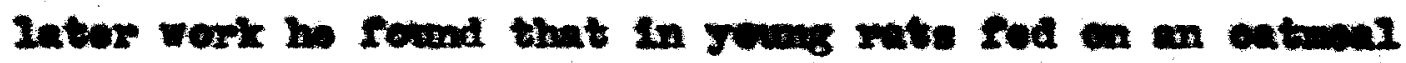

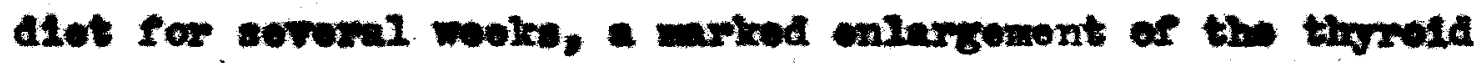

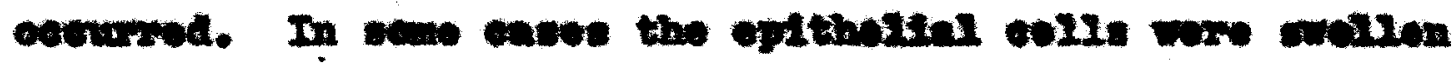
and cotachots

Bonales (8) found that by fovalng opowion an a

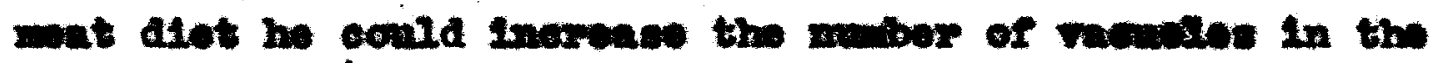

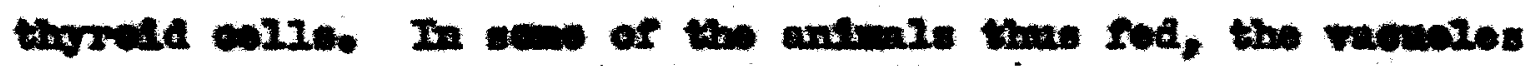

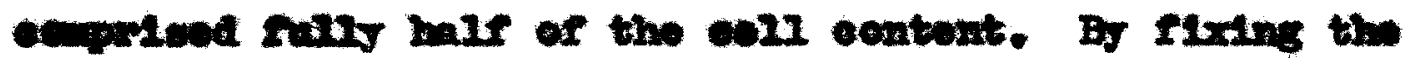

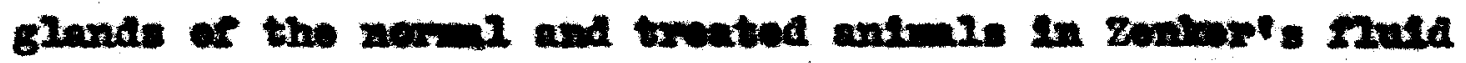

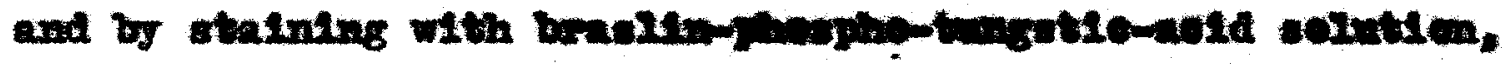

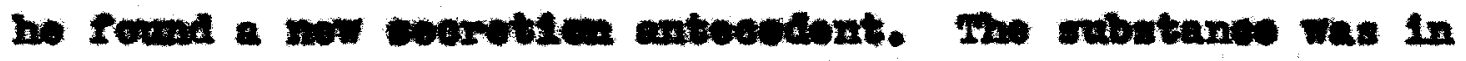

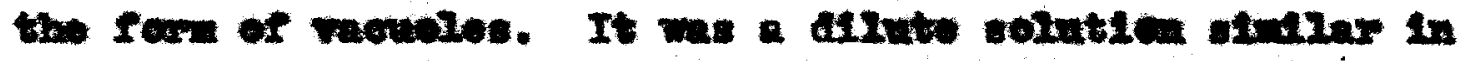

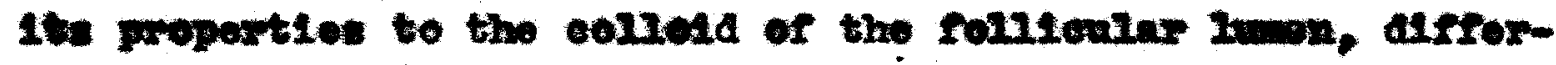
Ing ondy frem the Intter In donulty. Il stutes that the now 
mal vovroting oells of the thyreta soervtes dirwotly into

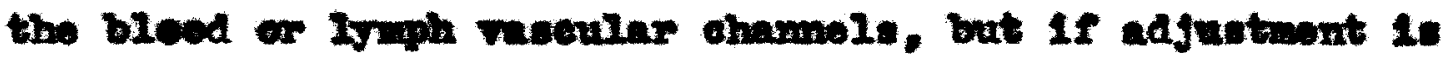
Alnturead so that the rate of seerotion is in expess to the bodky noeds, the Indiroot wode of seoretien is brought about, and the preduets of the weervition aro stored in the Intorielilewiar eavity. Aocuraling to this coneeption, the

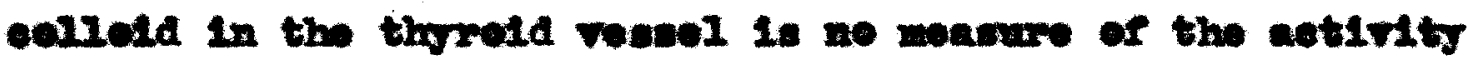
of the eland at the time of obeorvation. A1se, the Iapk of colledd in tho gland doos not nocosearily moan that thow me been dofletones in the setivity of the gland, though it does mean that thore has boen a derletoney socrotien or olso the fland has nower rieon above the lovel of a secorotery rate noeded for atreat expors.

Thoxe have been wary experinonte to show the

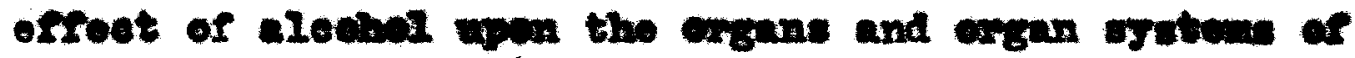

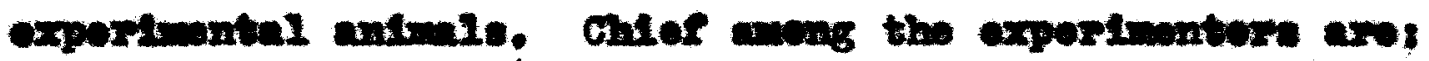

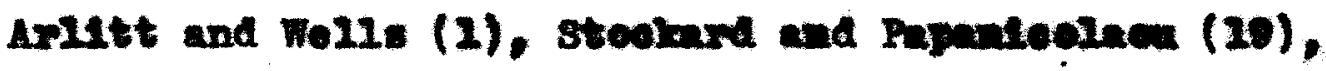
Poarl (24), Richtor (16) and Soltman (18).

ArLtt and Wolle (1) ropoeted that the sondmiotratien of aleobur in the food of wals whte rate for two

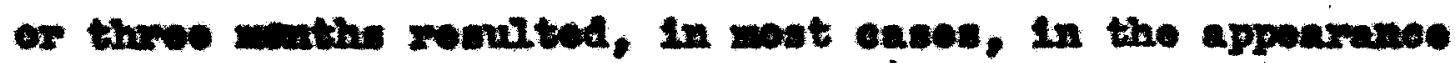

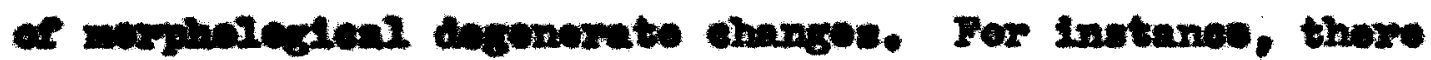

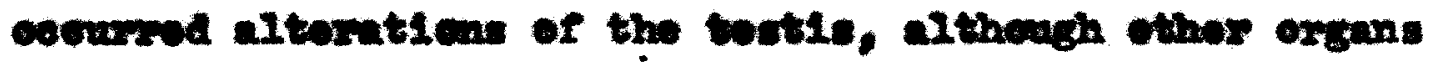

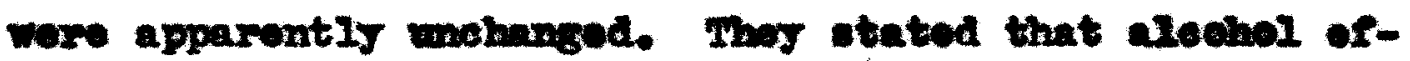
foots the stope in spoxwatrovanele, and that befow storl1-

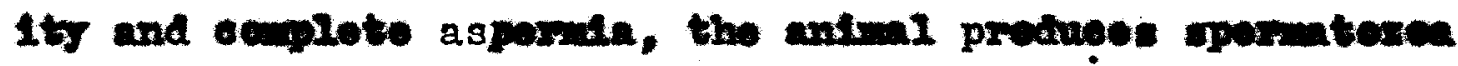
ohnrapterised by all aegrees of abnormallty. 
Stosiand and Pajanteolnow (29) found that by troating guinea pige with funs of alechol for one to two houre cally, thore wa no ohane in the exterinal appearanes

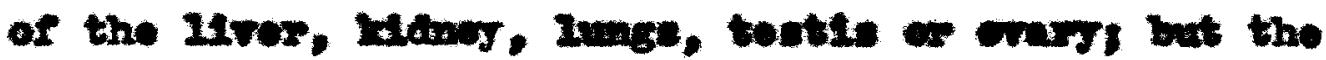

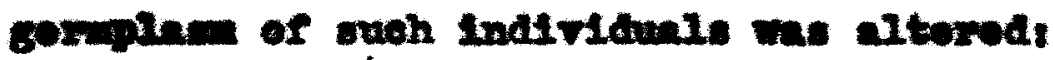

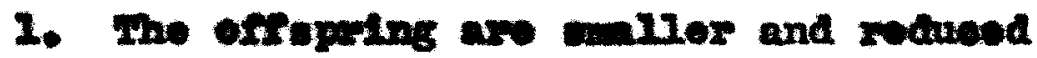
In mobs

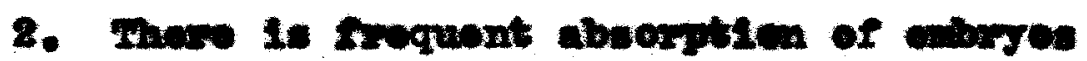
In the alochallecd nothows. The Iattor

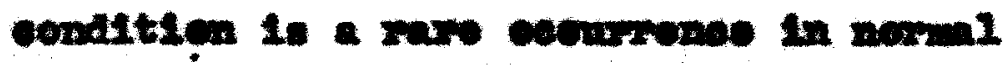
mothoris.

Poarl (14) gavo Barred Flymath Reol ondebens

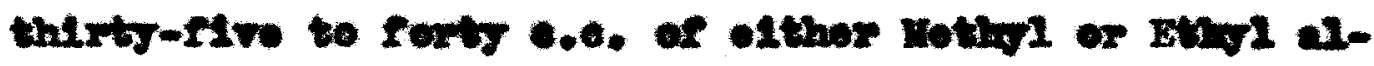

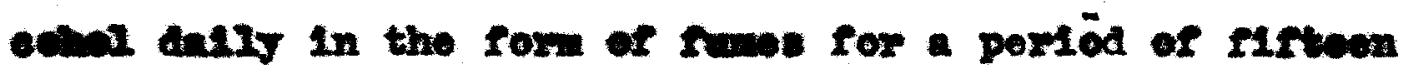
wonthe and noted that the mortallty of the troated bixde

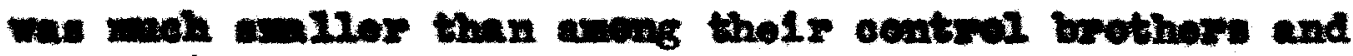

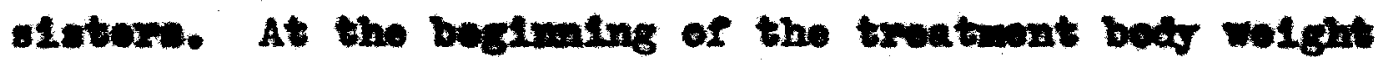

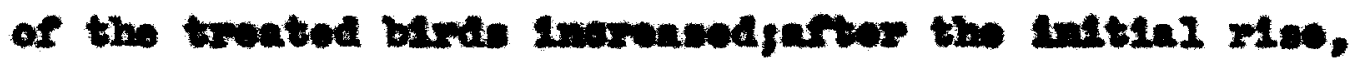

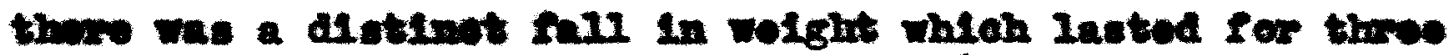
nathe, to be followod by another rive. At the coneluelen of the exporimont the bedy wolghte of treated birde wore

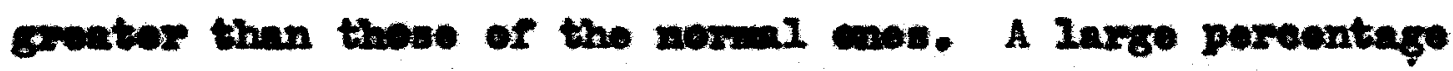

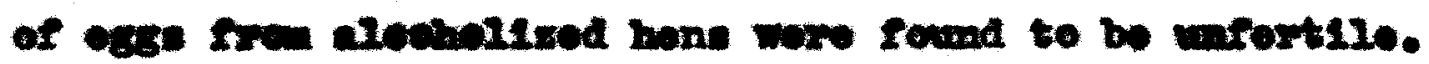
Rlehtor (16) found thet woonglaed rats (given alcohol dally in water, elght to olxteon per cont of the velwas of witor) ato loss than ceatrel rats. The animals welghod the same at waturity and soomed to grom as raphas. 
Solimam (28) round that tho centimgas couwoptien bs rats of Btugh alcehal, in dovos 2.7 to 0.40 .6$.

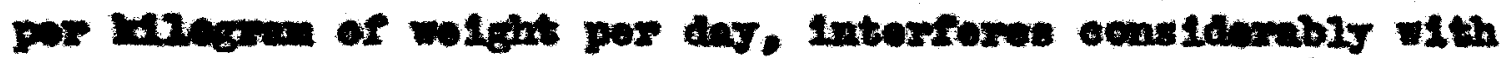

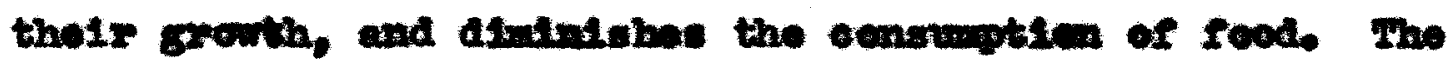

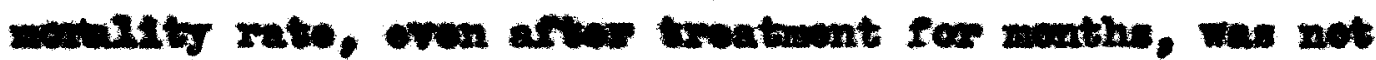
Iares.

The magens for ohooding alookd as the broatIng agont wow!

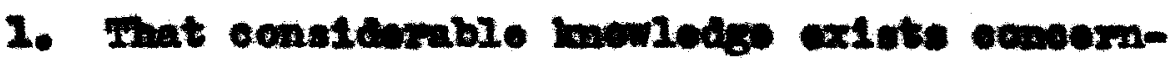

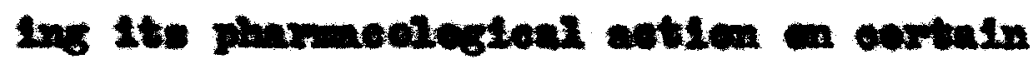
anteral temas:

2. It is known to be an organito mubatanee

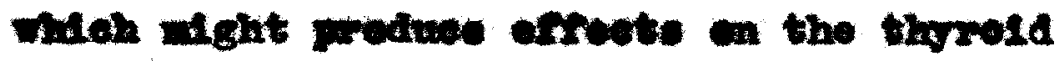
gina:

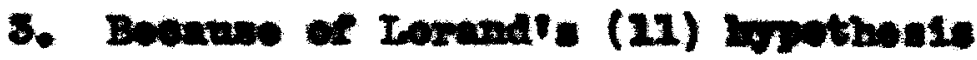

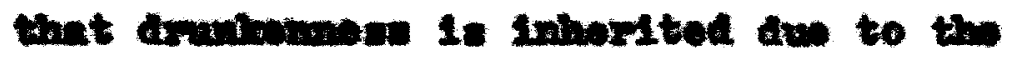
matrieation of the throud glend, mion,

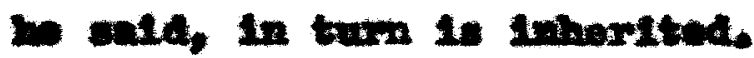




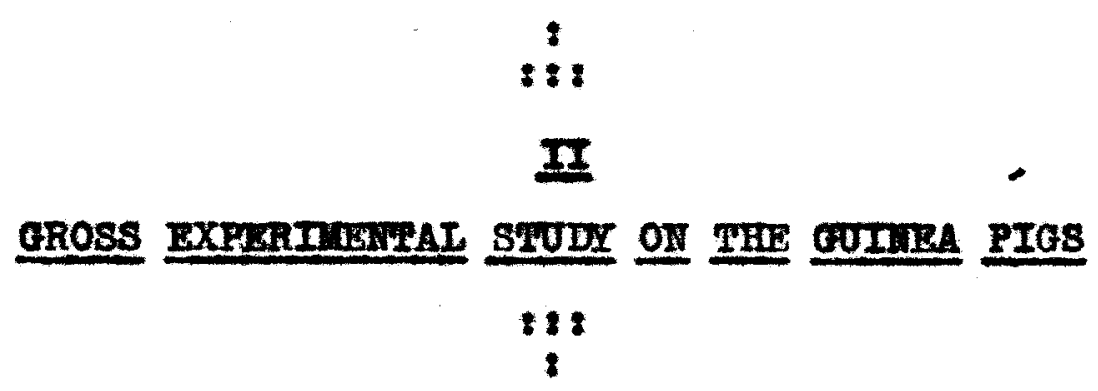




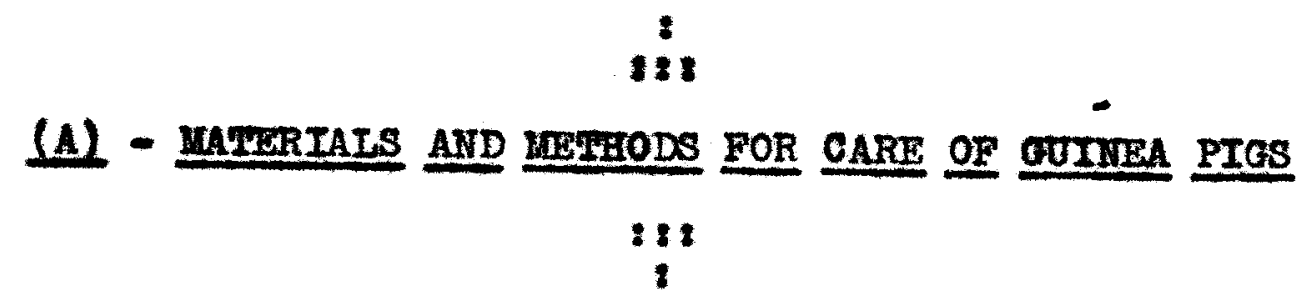


A group of olxteon guinoa plge, olght males and olght fomales. we cbtainod frem a roliable breedor. Ir. Iott1e Wahand, in Soptembor, 1950, The animals woro rren these 11tters.

1. Iftrey ene oontalned the follewing animale:

Mif, 42 , Ast, and $M \sigma^{\circ}$

2. Intter two contalnod:

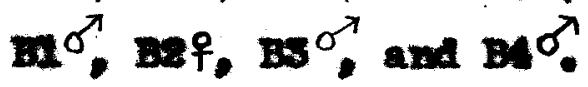

3. Iltter throe centelned, $\mathrm{Cl}^{\sigma}, \mathrm{C2}$. cos and and

$\mathrm{DI}^{\sigma^{\prime} \text { and }} \mathrm{De} \mathrm{O}^{\mathrm{T}}$ were the orfupring of $\mathrm{Az}$ f and

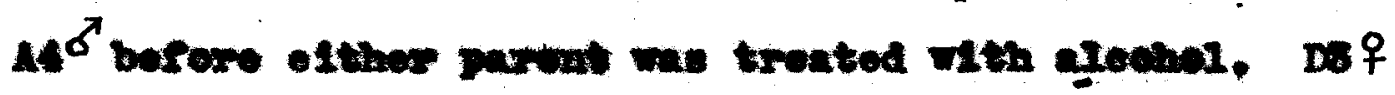

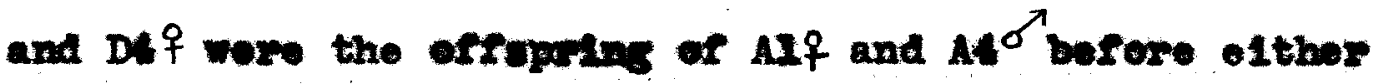
paront we troated, The average age of the andmals whon

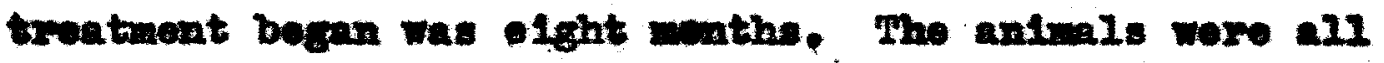
strong and vigerven in appearanee, on 0etober 1, 1900,

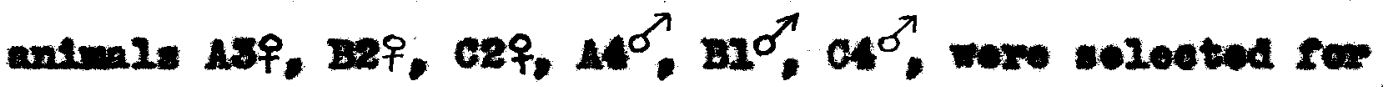
alecholic treatmont. Tho oholee was ontiroly at randem, thore was wo orldense of superientty or inferiority in the antmil seloeted for treatment agalnst those eeleoted as centarels. The entmals rotained as controls weres

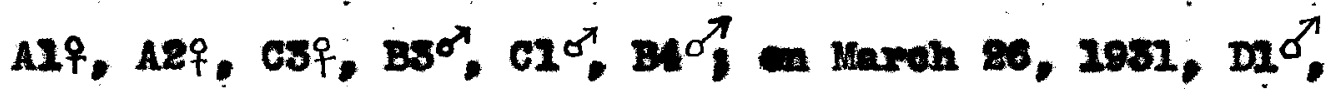

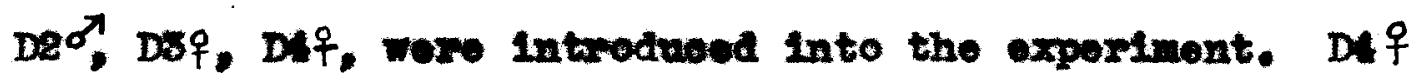

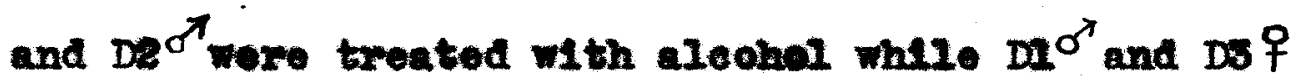
wore rotained as controls.

Treoughent the experinent Ethyl aloohol was adinletered to the guinea plge ervily by means of a 
pipette. 5 c.e. of olther 19\%, $27 \%$ or 30\% conoentre-

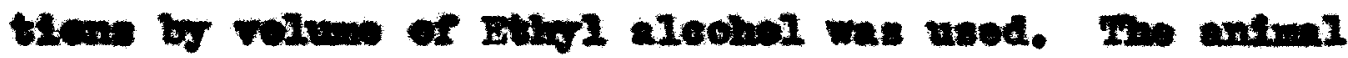

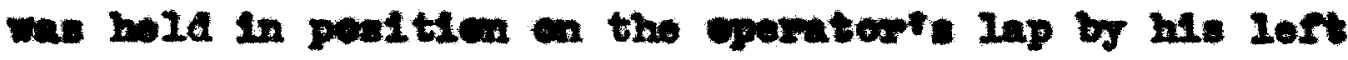
band and the pipotte wa manpaleted with the right hand. With a wort peried of conditienalng for the antmal and Improvoment of teemalque on the part of the prouter. the entmals wore nad to cenowe the alechal.

At the bectunting of the exporimont, 5 o.e.

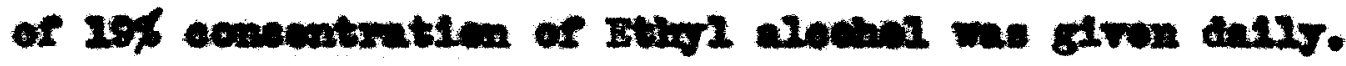

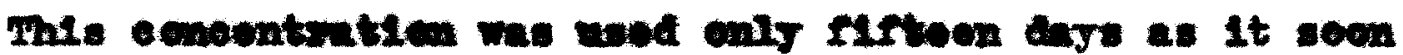
beame orfdent that the deglred Intexientien was not belins

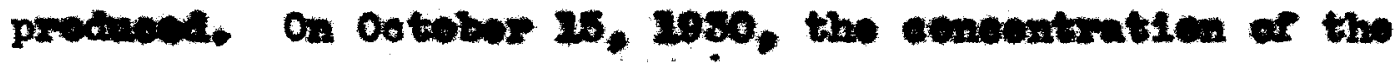
alechal we inoreased to ET/. This counce was not jot adequate for the desirnd intoxication and we en. Hevember. 6. 2050, the cencentratien was increased to 33\%. Frea this date throughont the experinont the deange ruminod the anas.

All of the foline ples, beth exporimontal and contzel. wore kept in the sam type of eage. Tho eages wore bullt on tho Indiridual eage plan. Ono luteh was conotruted whoh containod forts cangartmonts. Eadh cenpartwont win two and asomalf root lang by one foot wide. Bach eage was large enough to acosmodite ono animal,

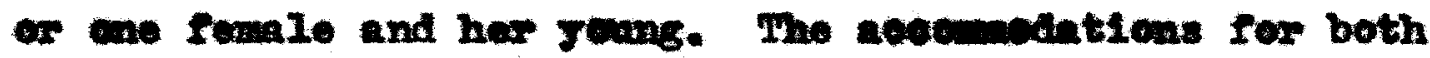

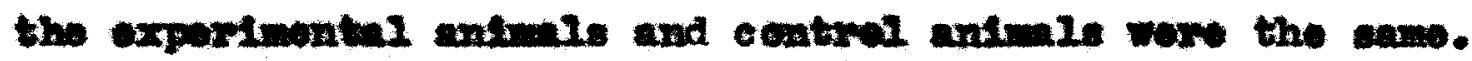

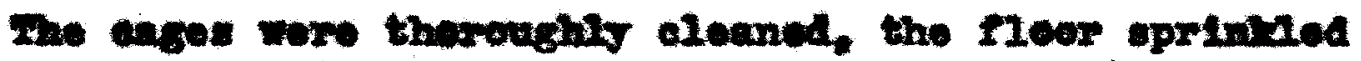
With sovennt, and in winter hay pat in tally. Each animal, eentrol and experitrental reeelved approximately 500 grams 
of read por dat. The rood consinted of two kindes

2. Dey rood:

2. Groen rood.

The ary rood contulned the rellewing eenAltutentes

1. Raved onte - 45\%

2. Bren $-35 \%$

5. 0 L How - 56

4. Tuninge - $5 \%$

B. Holaves Food- $10 \%$

The eroen foed conteted of aroen regotablos

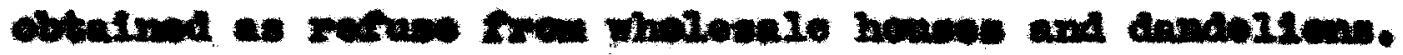

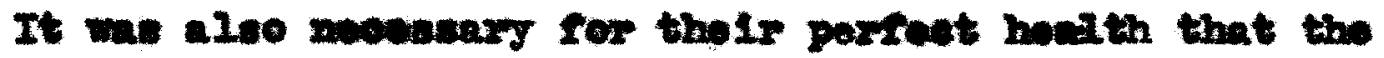

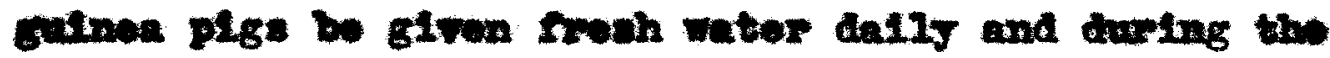
nuer It was found adviable to obange the water twies each alay. 


\section{2 \\ 18}

(B) - MATHGS OF THE GUDEA PTaS

$$
18
$$


In mating the animals, a male and fomale were plaeod in a ooppartant (boodsng pen) dweing the fomale eostral poried. Hatings of the antmis wore mado aftor axportwontal antwals had beon troated with aleohol for firven dare. Arter the wale and fomale wore tegethor for one menth, an exaulnation of the fomalo we made. It consteted of rooling the horm of the atorwa to atormine the muber of chibryes. The follewing mtings wore mads

$A^{\sigma}$ ale. $X$ Asqale.

44 $\sigma^{x}$ ale, $x$ Ast

Bef ale. $x$ Bso

$\cos ^{\pi} \times \cos$ 우

as are. $x$ cet ant

BS ane $x$ ceit are.

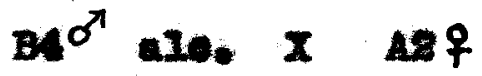

Dof $x \quad \operatorname{ma}^{\top}$

Dif Derate.

Caxolu chactrations wore mad dally to ob sorve the condstien of the pregrout animis. Hot a eingle

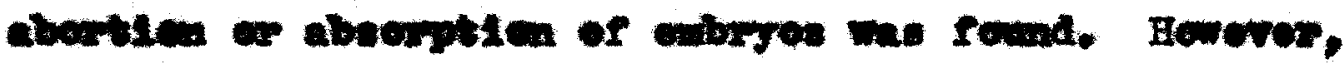

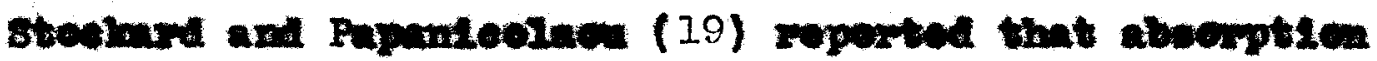
of cubryo by aloeholized wothore wat Irequent.

The rocult of the above metinge weres A $\sigma^{\top}$ are, $x$ Asit ale. 5 nowal young

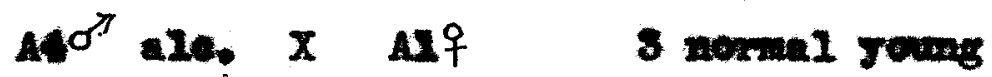
Bet ale. $x$ Bs $\sigma^{\lambda}$ i noxwal rowas c2o $x$ cof 5 newreal rowns 


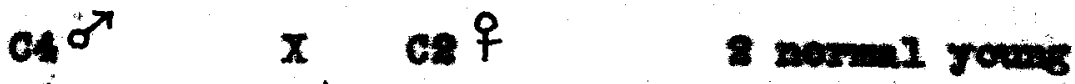

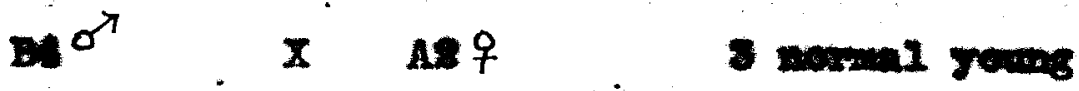

$$
\begin{aligned}
& \text { Dif ale. } x \text { De } \sigma^{\gamma} \text { ale. } 2 \text { normal joung }
\end{aligned}
$$

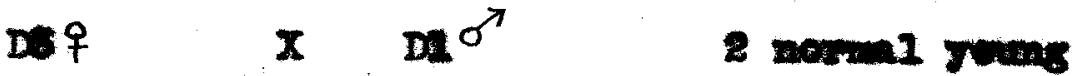

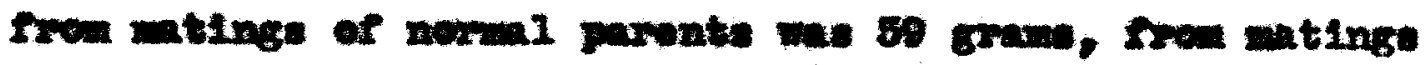

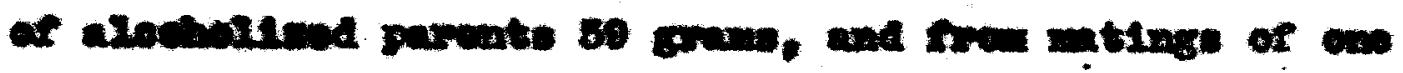

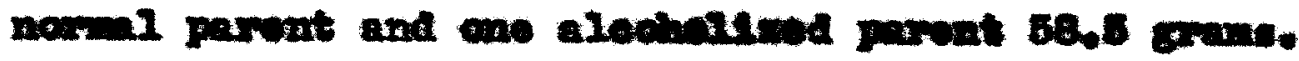




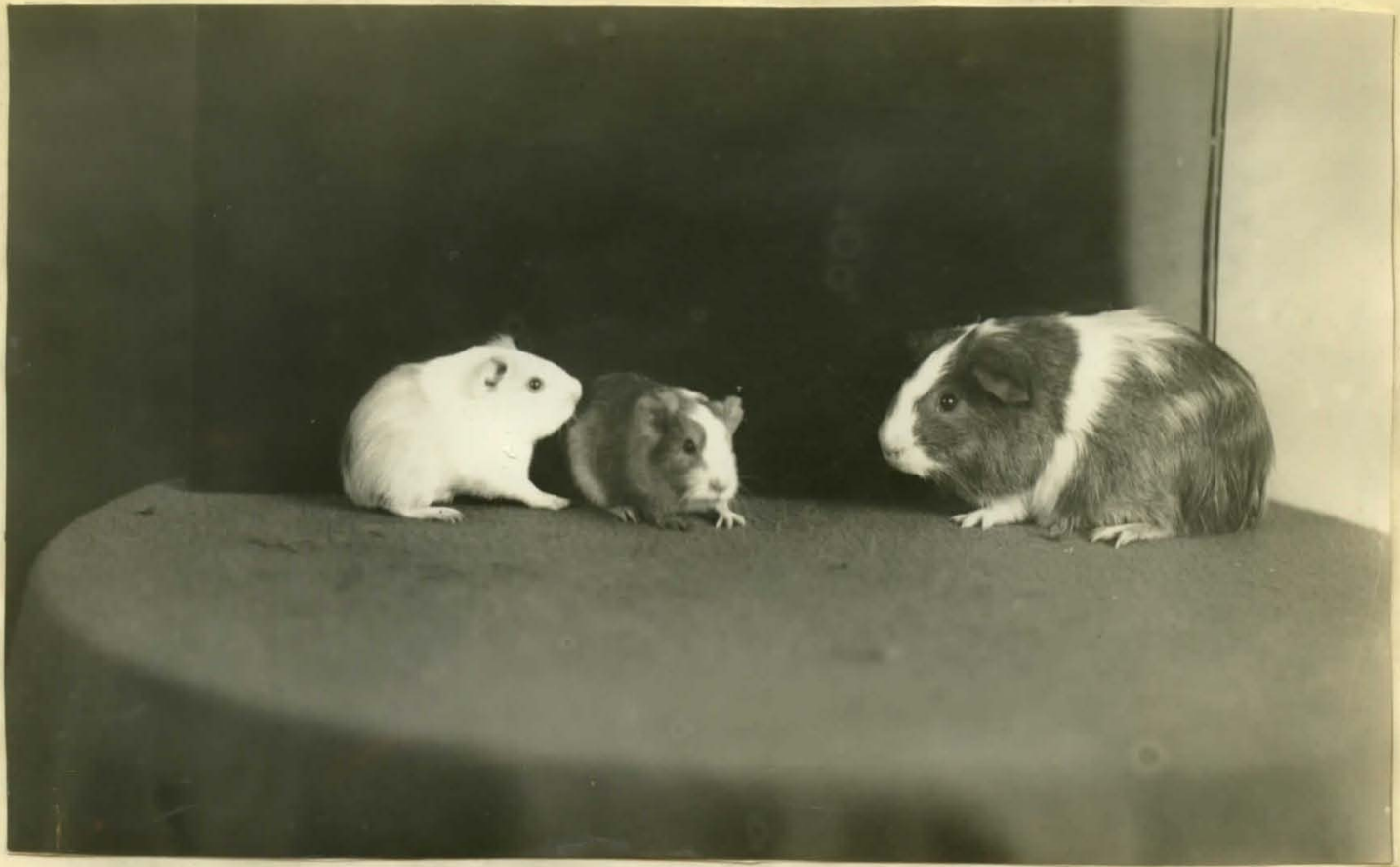

Flgure 1 shows a nomal fomale (D3) and hor orfspring from a mating with a normal male (DI). (Photograph was taiken when the young wero ton days' old.) 


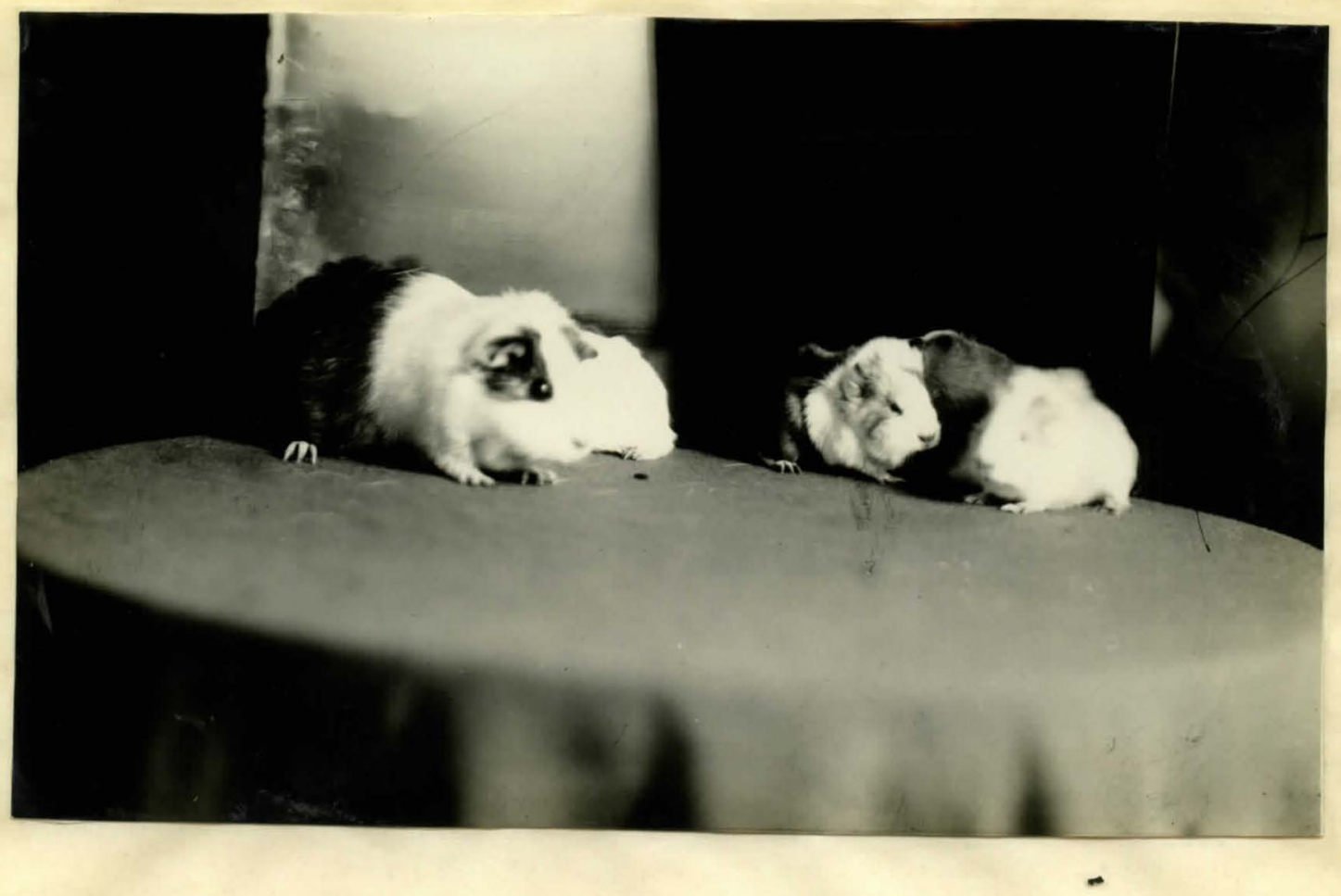

Flguxe II showe an aleoholized semale (DA) and hor offspring from a mating with an aleoholized male (D2). (Photograph was taken when the young were ten days? old.) 


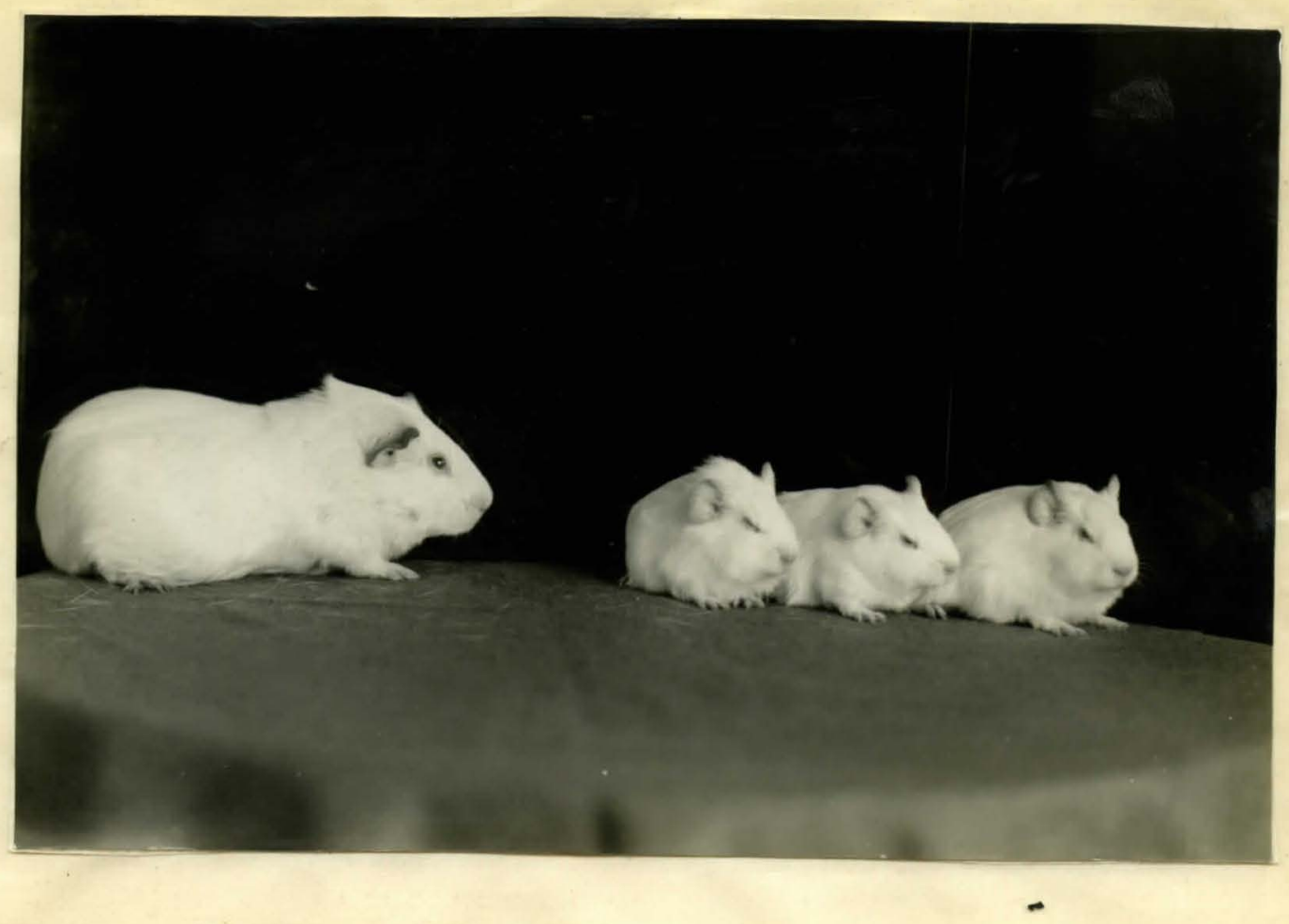

Flgure III shows a normal fomale (DA) and her offspring from a mating with an aleoholized male (D2). (Photogreaph was taken when the joung were $\operatorname{ten}$ (ays' old.) 


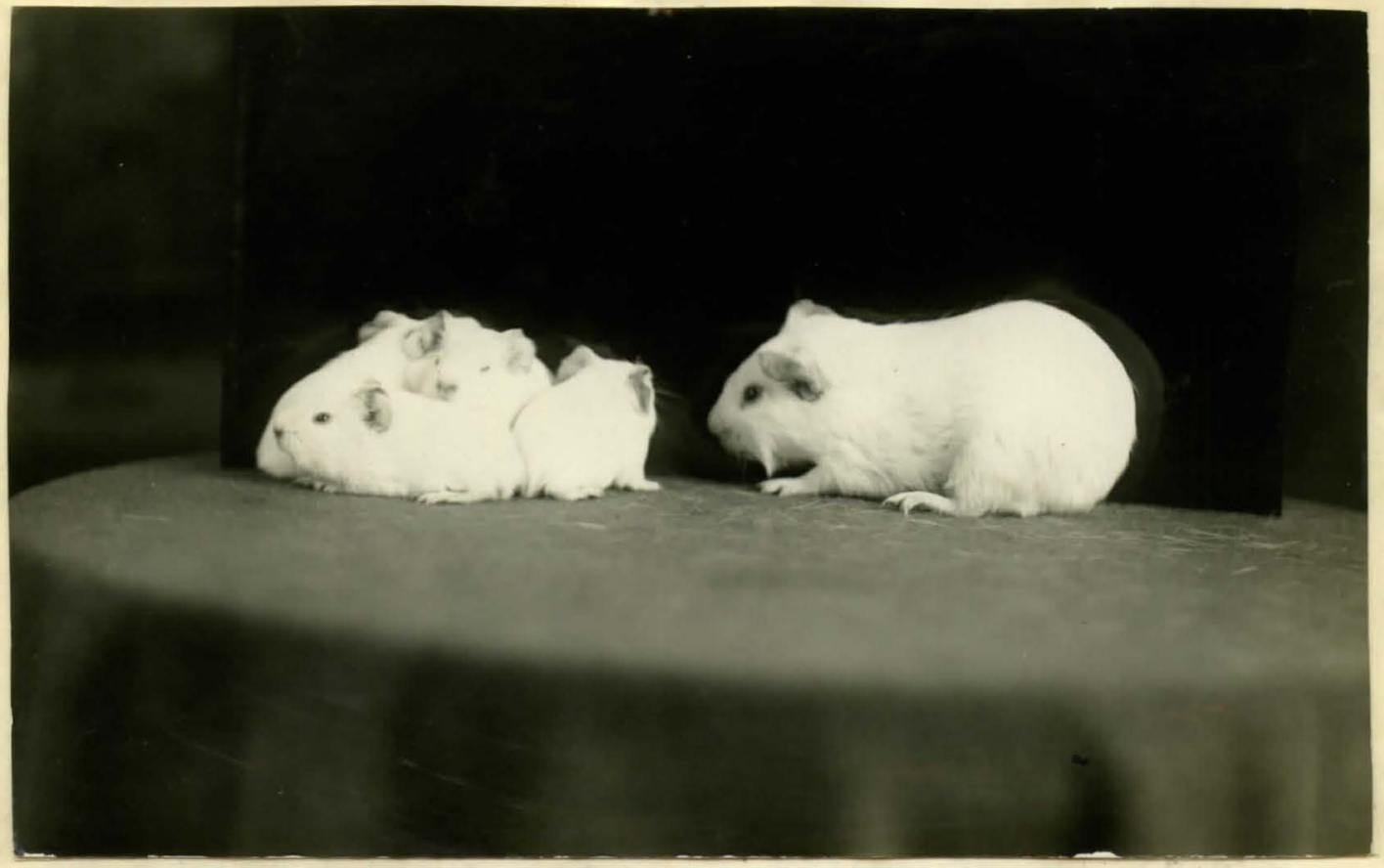

Flgure IV shows an aleohollzed Pemale (BR) and how offspring from a mating with a normal male (B3). (Photograph was taken when the Joung were ten days' old.) 
1

(c) - GEMRRAI EFECHS OF ALCOHOI-

UPOA THE BODIRS OF COUDE PIOS

8:

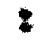


The genoral efrecte of 5 co. of $35 \%$ bingl

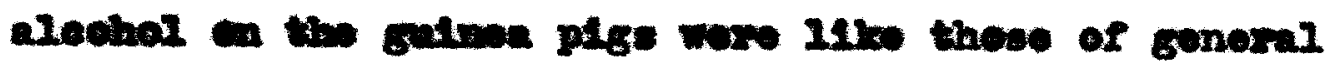
intorteaticins

1. A Inok of mocular coomalnations

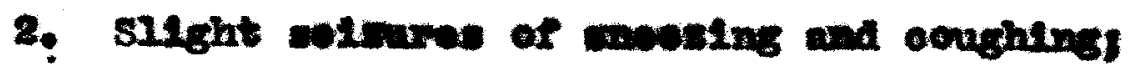

3. Wrtexy alsolurges from the morth and wose during the firet twenty days of troatument:

4. A glases conditien of tho ogons

3. Darooti in the roaction. Mon a ringer 10 jabbod at normal antmis thor rotront. but mon gabed at treated antmals they rumaln quite atiII. 
In a study of this kind, a compartsen of weighte 1 Inportant. Table I ahowe

1. The intilal wolght of each animal,

8. Tho total intinel worght of the alcohorlo eroup and centrol group of ansinale.

3. The wolght few woh andmi at twonty ang latervale tor 200 dayes

4. The fimal weight of aleoholio and conterel antwales

3. The rimal welght of alocholio and control groups after 200 dayes

6. The posentage of guln or 10as for. each entmal at the end of 200 degre.

Fre the table it $1 \mathrm{~g}$ ahom that aleohol ba no erfeot on watht and that wolpht eannot be weed as a

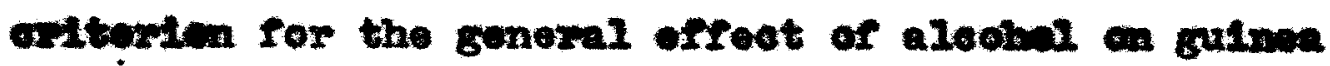
pige. 
Tablo I shows: (1) the initial woight of each animal, (2) the total initial weight of the alcoholic and control groups, (3) the weight of oach animal at 20 day periods for 200 days, (4) the final weight of alcoholic group and control group of animals, (5) and the percentage of gain or loss for oach animal at the end of 200 days.

\begin{tabular}{|c|c|c|c|c|c|c|c|c|c|c|c|c|c|}
\hline \multicolumn{14}{|c|}{ CONTPOL 3RMTP } \\
\hline $\begin{array}{l}\text { no. of } \\
\text { ani nal }\end{array}$ & $\begin{array}{l}\text { Initia } \\
\text { wal glit } \\
\text { grane }\end{array}$ & $\begin{array}{l}\text { Moi ght } \\
20 t h \\
\text { dey }\end{array}$ & $\begin{array}{l}\text { Wol ght } \\
40 t h \\
\text { dey }\end{array}$ & $\begin{array}{l}\text { Feiglat } \\
60 t i i \\
\text { day }\end{array}$ & $\begin{array}{l}\text { Wei fint } \\
\text { Botio } \\
\text { day }\end{array}$ & $\begin{array}{l}\text { Tol fint } \\
\text { looth } \\
\text { dey }\end{array}$ & $\begin{array}{l}\text { ielgut } \\
120 t i n \\
\text { dey }\end{array}$ & $\begin{array}{l}\text { Wof ght } \\
140 \mathrm{th} \\
\mathrm{dny}\end{array}$ & $\begin{array}{l}\text { Telelit } \\
160 t i n \\
d a y\end{array}$ & $\begin{array}{l}\text { geight } \\
180 t h \\
\text { day }\end{array}$ & $\begin{array}{l}\text { Tel ght } \\
\text { 2ooth } \\
\text { day }\end{array}$ & zeain & quot \\
\hline 119 & 708 & 815 & 556 & 523 & 548 & 555 & 562 & an11ed & & & & & 28.7 \\
\hline 129 & 599 & 899 & 490 & 431 & 448 & 552 & 559 & 562 & 660 & 672 & 650 & 15.8 & \\
\hline 639 & 376 & 332 & 399 & 503 & 526 & 461 & 471 & 482 & 671 & 674 & 77 & 80. & \\
\hline $83 \sigma$ & 368 & 372 & 491 & $50 t$ & $5 \% 9$ & 541 & 549 & 552 & 690 & 700 & 705 & 91.6 & \\
\hline $\cos \pi$ & 362 & 371 & 1,44 & 463 & 4,72 & 431 & 501 & 512 & 654 & 660 & $6 \times 3$ & 83.1 & \\
\hline $84 \sigma$ & 373 & 382 & 436 & 502 & 510 & 532 & 549 & 52 & 628 & 632 & 640 & 71.5 & \\
\hline 016 & & & & & & & & & & 685 & 699 & 2. & \\
\hline D39 & & & & & & & & & & 691 & 693 & .2 & \\
\hline Totals & 2866 & 2921 & 2826 & 2928 & 3013 & 3122 & 3191 & 2659 & 3303 & 4714 & 4757 & & \\
\hline \multicolumn{14}{|c|}{ ALCOHOLIC GROOP } \\
\hline 139 & 669 & 670 & 872 & 533 & $4 \in 2$ & 474 & 488 & 562 & 720 & 722 & 730 & 9.1 & \\
\hline 829 & 325 & 334 & 423 & 488 & 492 & 532 & 548 & $5: 1$ & 680 & 690 & 682 & 109.8 & \\
\hline 029 & $3 \pi$ & 339 & 362 & 139 & 450 & 459 & 562 & 555 & 576 & 577 & 590 & 73.6 & \\
\hline 148 & 664 & 672 & 615 & 601 & 614 & 632 & 628 & 618 & 710 & 700 & 713 & 6.9 & \\
\hline 810 & 332 & $3<7$ & 408 & 501 & 5,22 & 532 & killog & & & & & 60.2 & \\
\hline $\mathrm{c}_{4} \sigma^{7}$ & 380 & 392 & 490 & 453 & 1,40 & 492 & 494 & 482 & 610 & 621 & 635 & 70.8 & \\
\hline 148 & & & & & & & & & & 685 & 692 & 11.02 & \\
\hline 026 & & & & & & & & & & 690 & 691 & .14 & \\
\hline Totele & 2704 & 2774 & 3170 & 3024 & 3001 & 3121 & 2721 & 2798 & 3296 & 4685 & 4733 & & \\
\hline
\end{tabular}




\section{III}

8

:8:

EXPERTDENAL STUDY OF THE THYROID GLAMD OF GUIMBA PIOS $\div 2$

3 


\section{8 \\ (A) - MATERTIAIS AND METHODS FOR THYROTD STUDY \\ 18 \\ 8}


On Jawary 29,1930 , the firat alochelle animi was illed and sectiens wore mode of the varlous glands (Ilver, kidney, adronels, thyrota and spleen). When those t1esues wore croied it was noted that the thorota showed an abnormal appearanes. All othor glands appeared normal. Beeause of the oonditien of the thryold It wa deolded to linit the study to this structure. In all. sixteen glands (elght experimental and elght oontrol) have beon seotionod and gtudiea. The animis rrom which the gland were taken varied in age from eleven to fourteon months.

The throld tiemse was obtainod imodiatoly arter the enimals wore liled, Host of the tissue was I1xed in Bouinis Inda rrom twelve to twonty-four hours. In somp

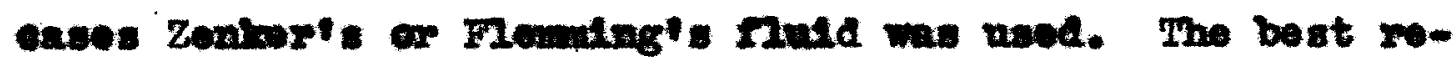
oults were obtained when the glande wore fixed in Boraln's ealution.

The glands were imbedded in parafrin and out at elght wiorons (ceeasionally twelve worons). In a majerity of anses sections were taken from difforont parts

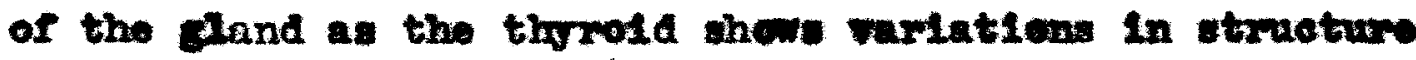
in ite alferont rogiens.

A11 druvings wore made with a Ielt: 4 mo objeotive aith a 15x ere plece, giving bout 700 diamotors' monifleut1en, wth the ald of an Abbe Camora Inelda, at bar Iongth $125=$

An ordinary Baweh and Lowb woramotor oyo plece $7.5 x$ was used in all morauromonts. 


\section{8}

(B) - THE MORMAL TERROID GIAND

118

1 
Tho throid gland in guinen pigs is batter21y-wing sheped. The two lobes 110 on the lateral surfaees of the trachea and Inrme. Tho 10bes aro jelned by a narrew, almost invi alble 1athwas. The gland in all

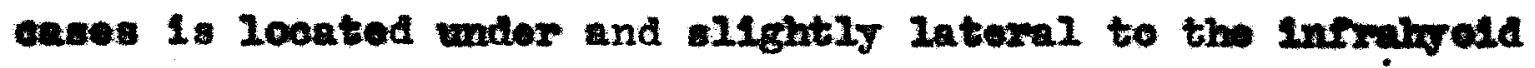
mascle. The weight at the time of auteger ranges from .o to 1.4 gram. The average welght rwo alechollzed animald was 1.02 grems and from control animals 1.08 grams.

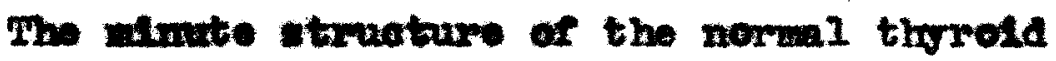
gland of gulnoa piga it shown in rigure flve. The follieles of the gland in normal antmals are rounded or oval in shape and rary from 12 to 148 miterone in dianoter. The imor and outor ell walls ax distiret.

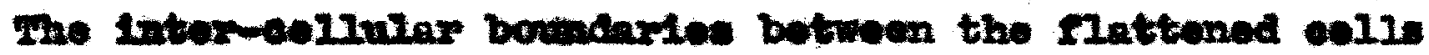
aro Iese distinet, and sombtimed no boundery at all can bo made out. Ims way be due to the fast that the Mattenod cella stain deeply.

The groplawe of the follioniar ooll: 1: filled

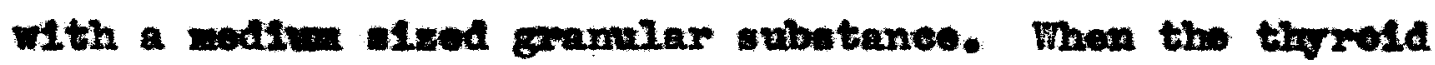

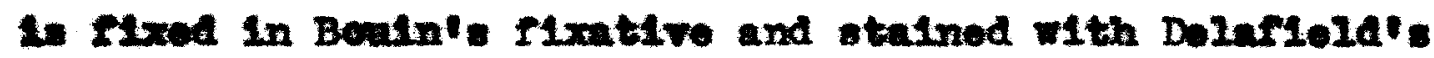

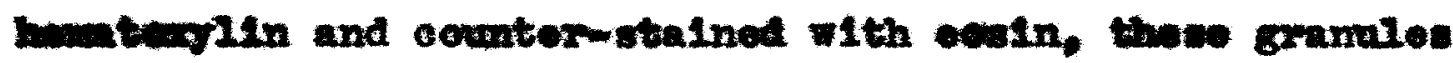
are blwo. Whon rixed in Zewher's fixative and atainod in

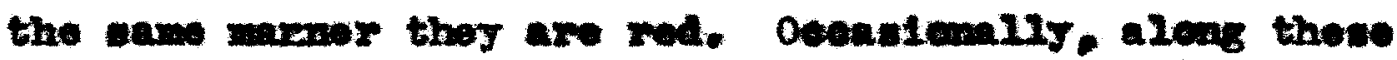
strunde of gramules thare way bo found a durte, elear, watory vacusis interposed botwoen adjacont gramalos. The cella present a falrly uniform appearanoe and thore is nothing in the ogtoplasm or moliexs to indi-

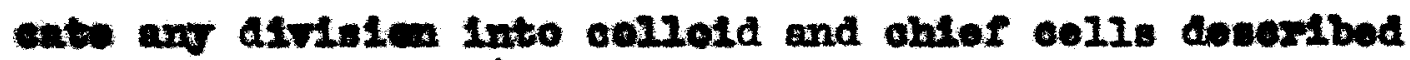
of Inomonderes (10). 
The waslel of the rellieular opitholtil eolls are olightly ollipodial in form, thoir diomotore range frem 6 merone to 8 mierons. The average is 6 werons. The meoloar mombreno is diatinct and stains sightiy doopor than any other part of the mulove. There are rrom two to throe moleol! and serreral smaller gramiles foumd in

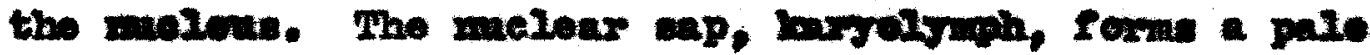

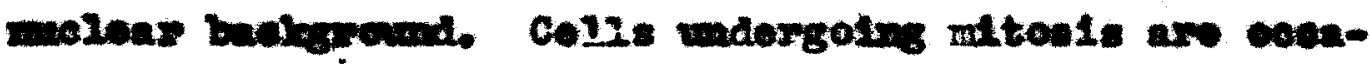
oleanity soen.

The oelledd shown in Plgare riw is typteal in form. Porlphoral folltelos are woh larger, hewerer,

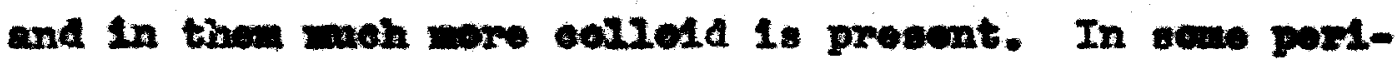

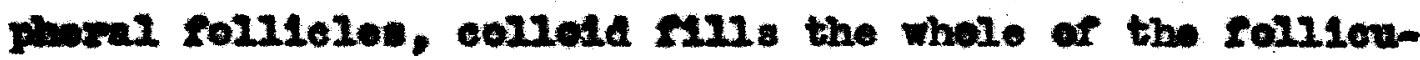
lar eavity. In the doeper follieles the colleld coenples ealy the cemter of the rellicular eavity and does not mine contade with the opthollal colls at ans podnt. This rotractiea way or mot be an artifact dus to slurininge eaveod by fixing roagents. Vaendios are not munorou in normal glande, and when they are found, are amm in 8120 . and ape not absolutely clear. They stain rery faintly with eouln. Those vacuales, when toand, masure from three to Plve aterons. Ther are ophorieal in shape and aro noar the surface of the collodd material. The positien of the vacuoles leads to the ascruptien that this racuelar materInl was probably aeoreted by the collotial epttholial oella. Interfolstoviar comective tissue is of the

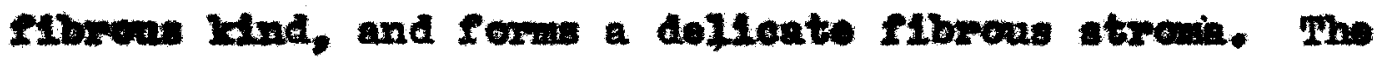


ancunt of compotive tiosue is mall, but contains a rich sapply of blood reanels.

In glands from control anterals, there are Irequontly woon dogenerated oells. Those may cocus in axy part of the gland. In some cases a single colletial epttholial coll way be degenerated, in others all the celle of a single folliel. way be In this conditien. These oells way romain in the follicular wall or thoy way be dosquamated into the follicular eavity. In some oases in glands Now centrol antmals, the author has seen dosquamted colla areuping the whole of the rollioular oartity. The ogte-

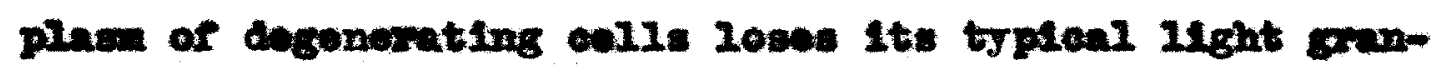
wlax atresture and bocoms racuelated and rotioular in appouranee. In Iater stage of degenesetion, the efto-

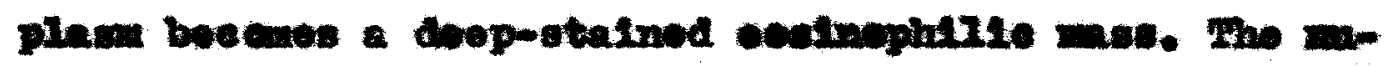

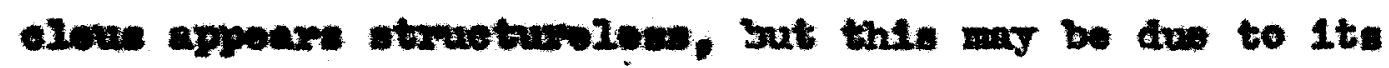
ereat arrintey for otain. 


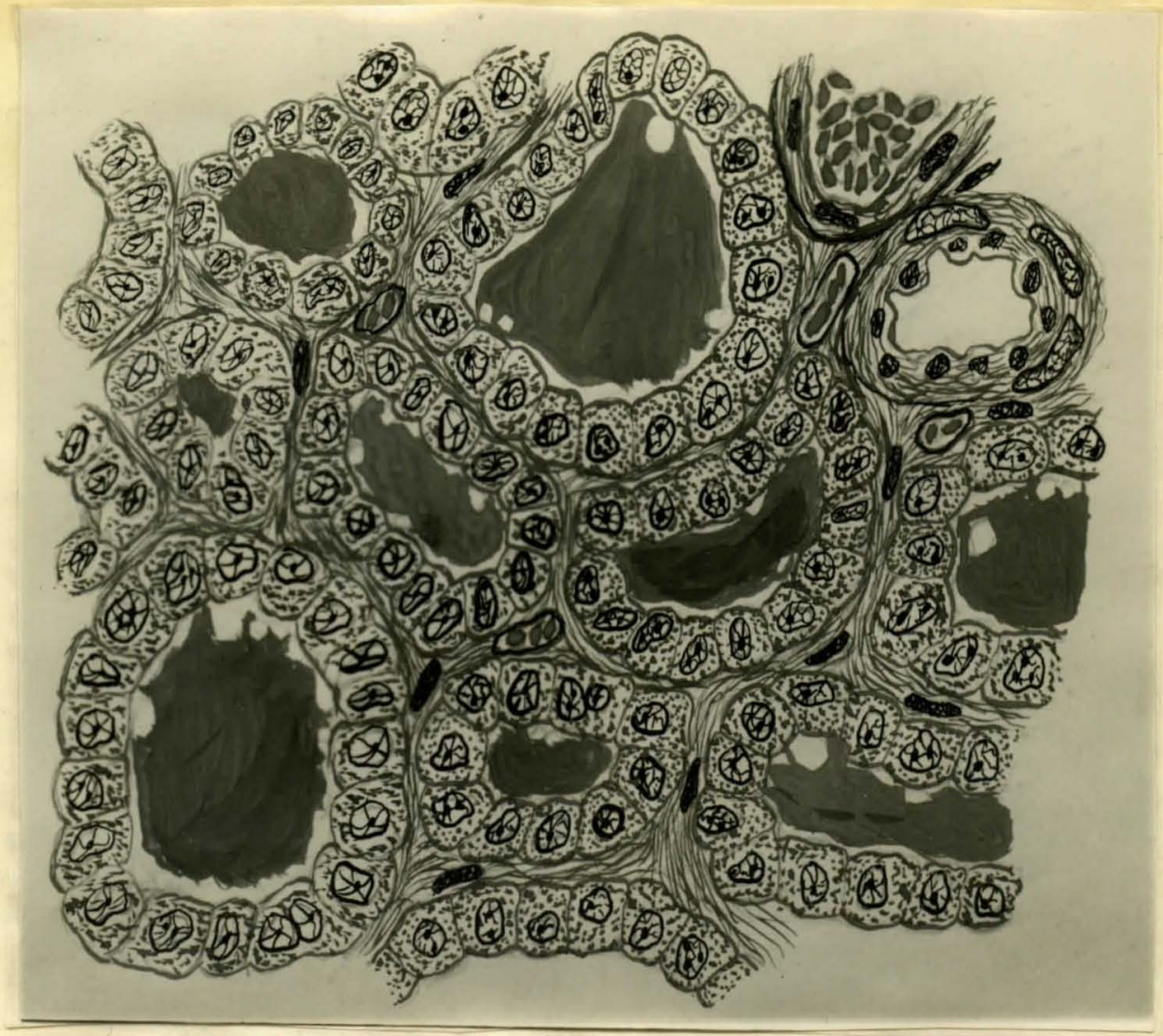

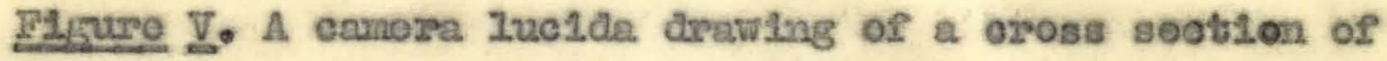
a normal thyrold gland showing several folllcles. The strueture in the uppex right is a voln with Its red blood corpuseles. Beneath this is an artery. Inside the follieles (which are ring shaped celivilar structures) is a mass of collold material, shown in darle gray. The white spaees in the collold material are vacuoles. The cells which make up the border of each follicle are follieular epithellal cells. The Pibrous material botween the follieles is connective tissue. 


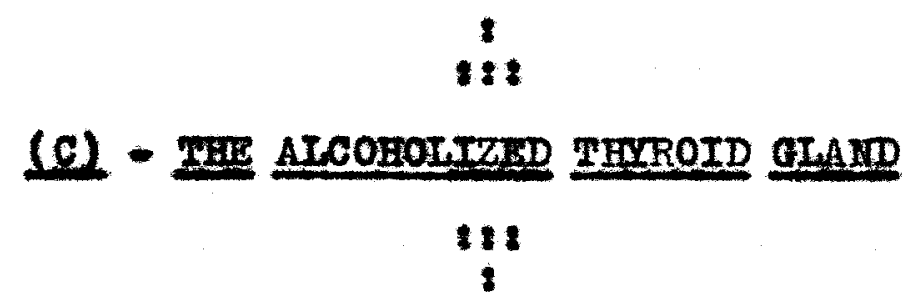




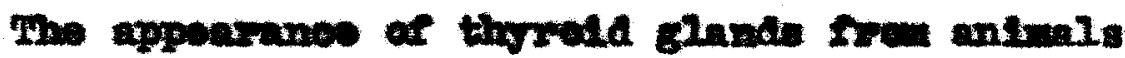
abjected to 5 e.e. Arem $19 \%$ to ouf Ethy alochal for

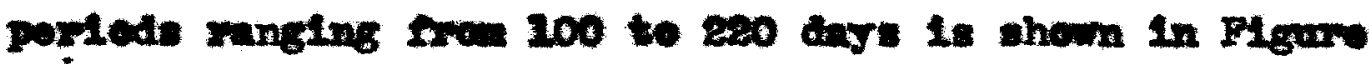

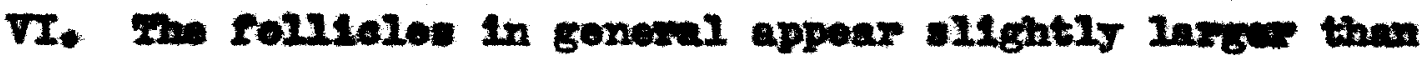
thees from glands of normal entunis. The afintma clameter of the follieles we 20 werene and the waxkm was 200

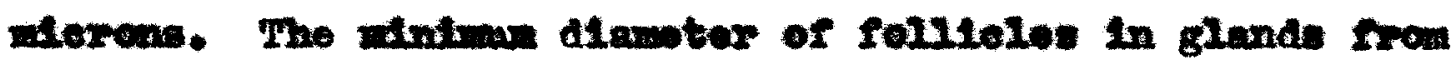

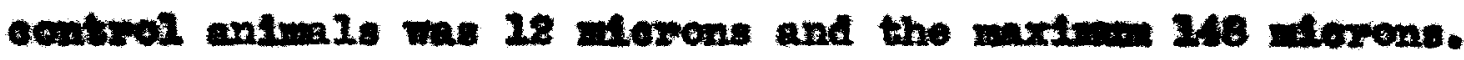
Two length of the optinelial oelis of the

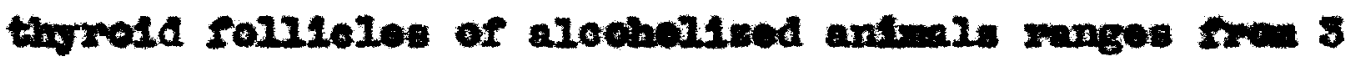

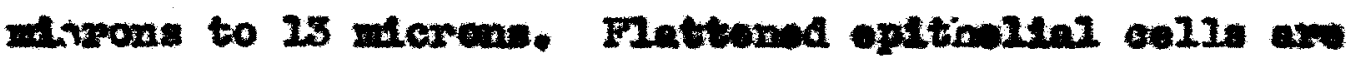

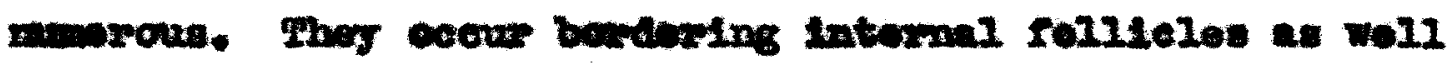
at portpheral follieloe. In glants of contrel antals

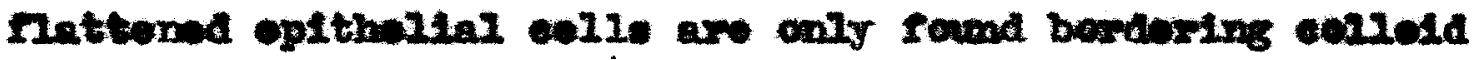
In the poriphowal regten. The evernge ates of celietial

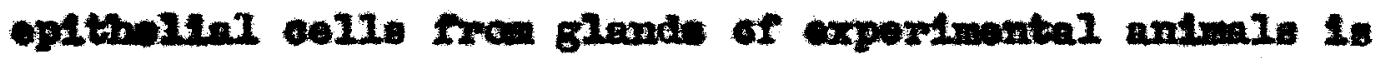

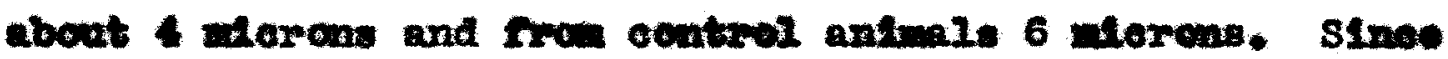

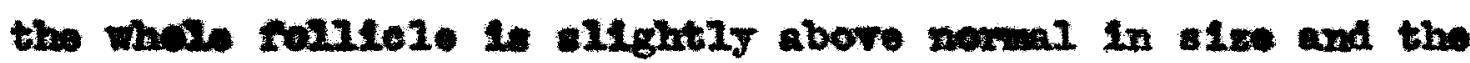
opthollal oblle aro silghtly below norwal in siso, It

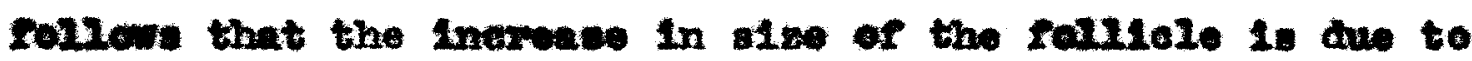
the inozoase in the collotd contont.

The ortoplaw of the follioviar optthollal colls

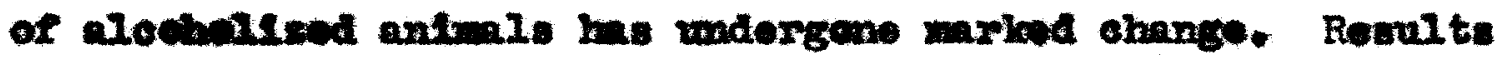

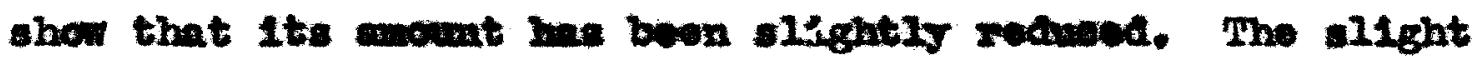

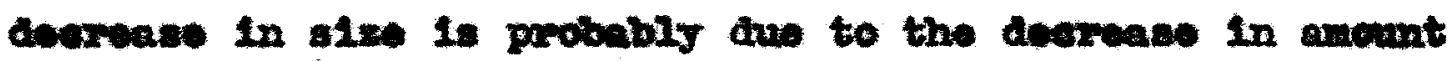
of ortoglawi. 


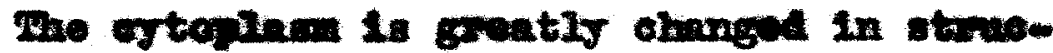
two. It is menty veouelated and the nownal indarintese wotsmann of cramiles has ontirely disappoared, though

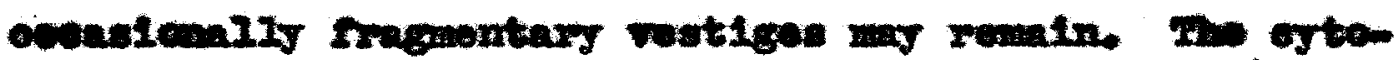

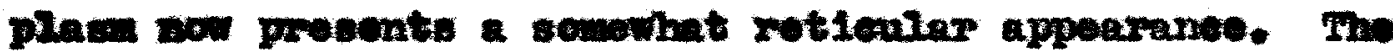

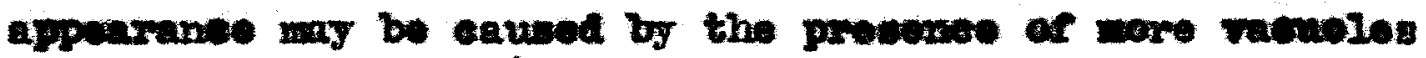
within the ortoplank. The exthor hat observad thow reve-

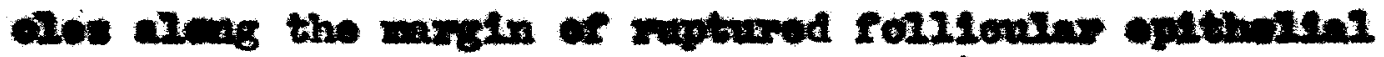

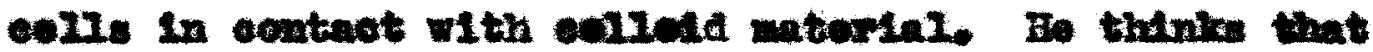

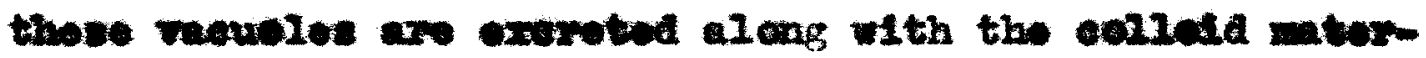

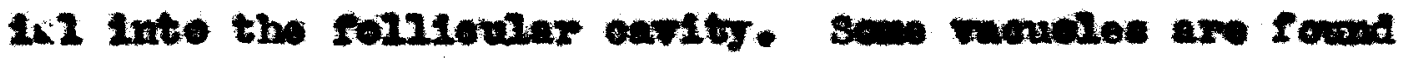

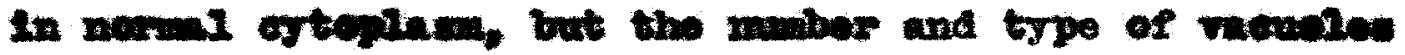
are alterrent in oelle of aleohnilsed antuale. Tho coares

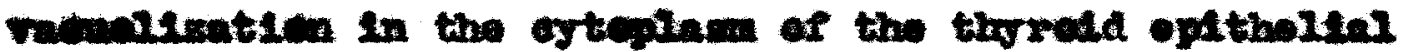
cells of alcoksized antula wa nower seon in that of eentoral anirnale.

The oyteglaen of the vory nattened cellese-

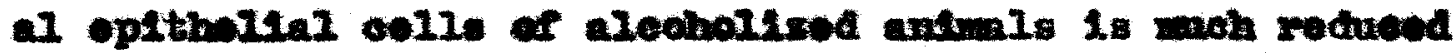
in sontent. Fore there is no retiewlar appearame, and

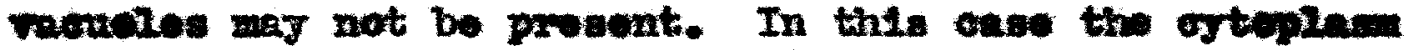

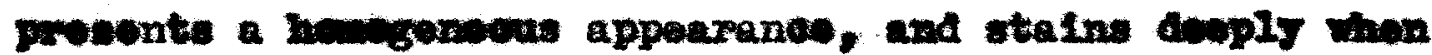

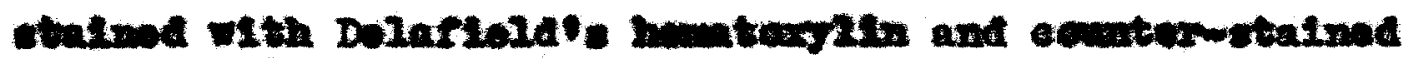
wth owatn.

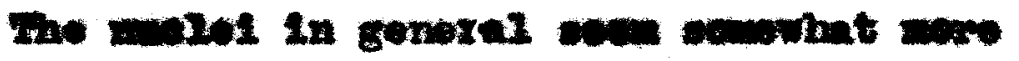

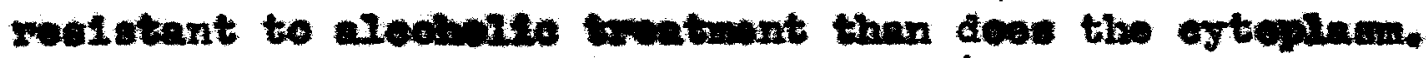
In form and lise the walet are notral. They range in 
Alumbtor frem 2 to 8 milorans. The avorage diamoter in both norwal and alochorised antwals is 6 meront. To

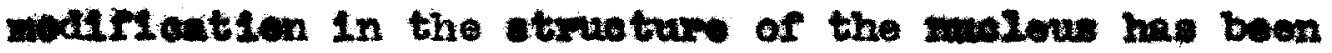
noted. Ho caves of mitotie or antotis aell divindon wore found in aleaherized antwals.

The colletd in follicies of glands trom alocholle animals has udergone chenge. Hore the largo and

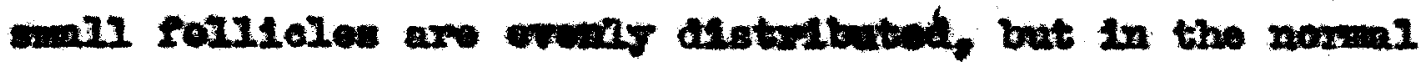

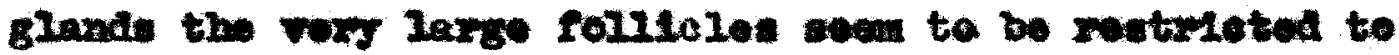
the portposes of the gland. As alroac montioned the

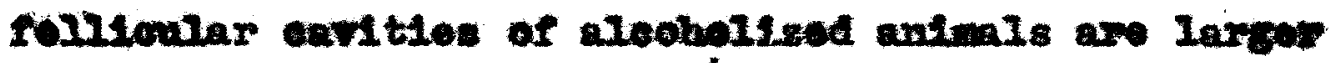
than thowe of nermel ankmis. The materiol within the

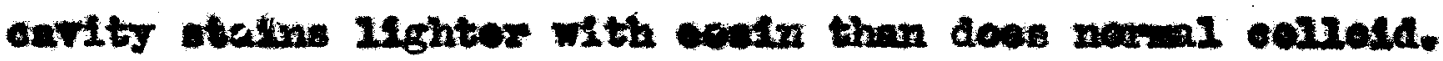

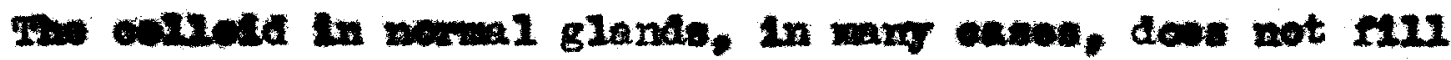
the whate of the roliloviar envity, but ta a large muber

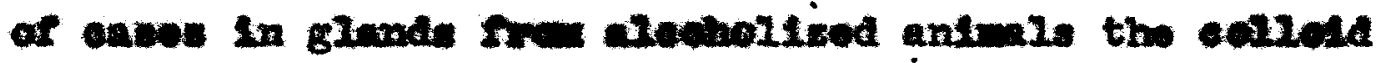

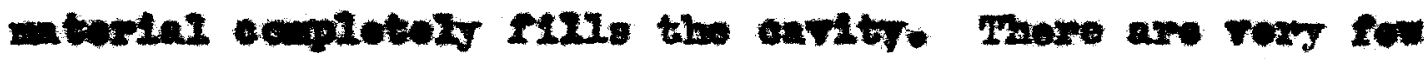

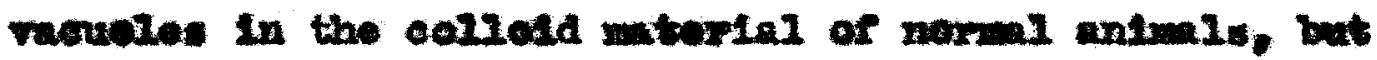
veculas are manorous in colletd material or treated andmals. As mang as 16 vacuples maty be ocunted within on

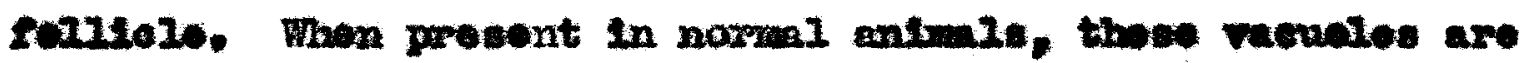

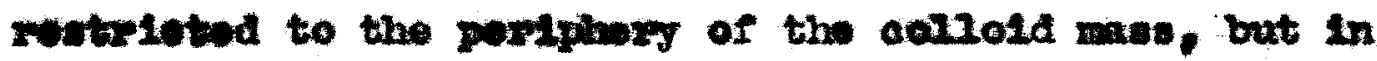

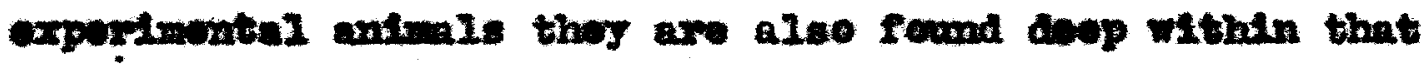

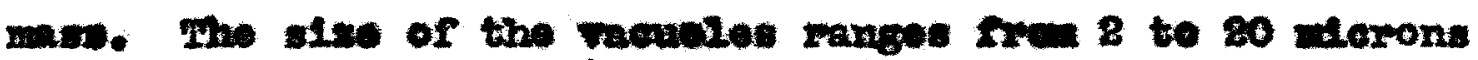

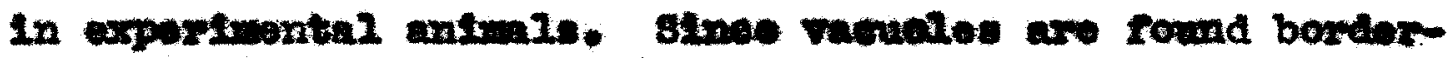
Ins the rollicular cavibs, within the opthelsal colls, and sinee It has been noted that the oell wall bordering the rollicular oavity aften disappoars, it is thereht 
thet this verueler matorial of the oglotan mos is a produst of the follioular opitholtrom. Tho intercellicuiar (Intorotitiel optho2ha) appoare to have undorgone sowewhat the swe charge

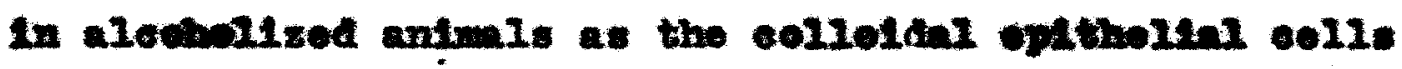
almady donertbed.

The ecmoetive tiande in the tropredd of antmal. subjeoted to aleohol appeare aleost nownal in andont and otruoture. In a fow oasos It appoarved that mere cempetive tiasu was present. The oridonge, hewwor. is not conelusive. If more comodtive tisan is prosent it way be due to an infiztration of a olear

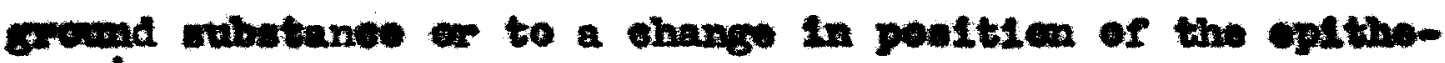

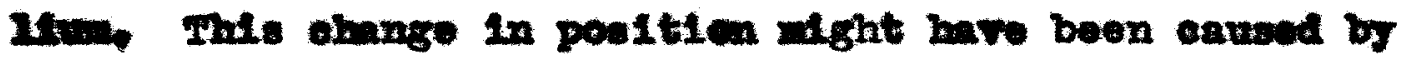
on Inereased peresure of the laxger oell. In the abnownal glands. The blood revells appoer quite normal. Thore are prosent in glands trom alcaholIsod answals more of the degenorated eell whioh appoared in normal glands. The degenerated eells cocur olngly

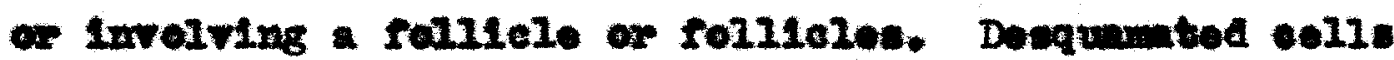

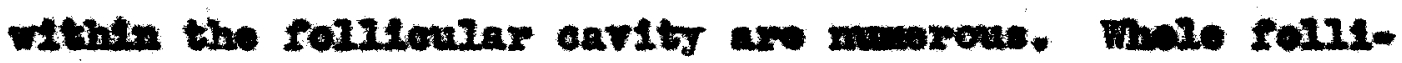
elos of aseguninted colls, mose orteplasm mas ocmplotely

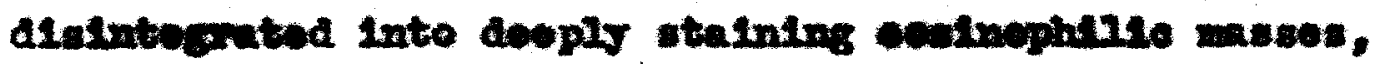
are rrequentis to be seon. In such oells the melol appoar onis a darl mabeen, ane to tholr afrinity for the stain. 


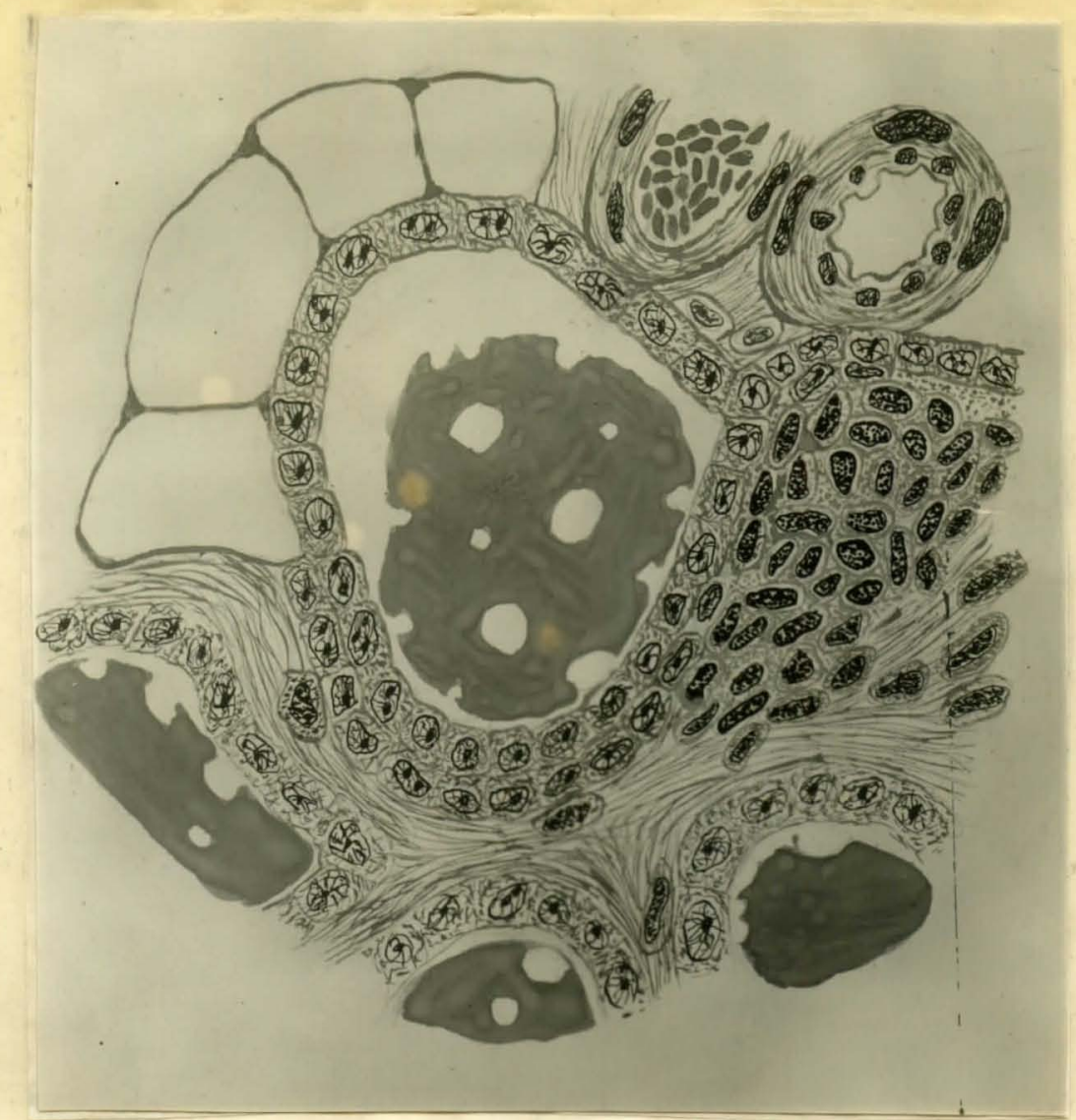

Flgure VI. A camena Iucida drewing of a eross soction of a thyrold gland from an alooholized guinea. pls showing a foll1ole and related stxuctures: The strueture in the upper right is an antery. To the left of this is a vein with its red blood corpuscles. In the center is a verry large follielo. The darik mass within the follicle is collold maturial. The white spaces In the collold matertal are vacuoles. The cells which form the walls of the follifole are cole loldal eptthelial ce11s. The rtbrous material outslde the foll1ele is connective t1ssue. At the right center are several dogenerated and desquamated op1the12a? ce11s. At the upper lort 


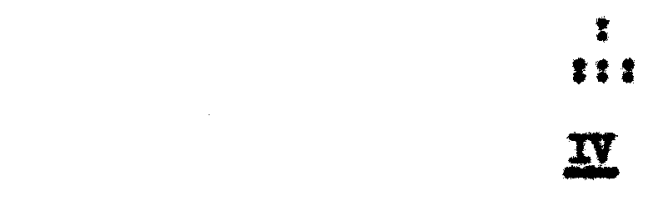

DISCOSSTON WITH REFFREMCE TO CITED LITERATORE

\section{1}

3 
Wh110 Ianguadente (10) Barine and Ienbart:

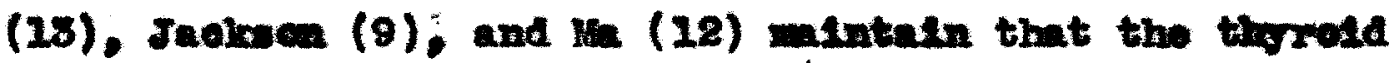
optthalial oelie of antale (dog, aboop, ex, plg and rat) pane timough a veerotory ejole in which the oelle present varlens modifleations from extanotien to rogonoration, the author rinds, howover, that the optholial eells in normal thymeld glands of guinen plge at the age of 140 te 550 deva, prosent a falriy unferm appoaranee. Whon fixed in Bouln's or Zember's Hultiro and stainod with Delariola's howtecgilin and ocunterstainod with oosin, tho staining 1. unifor in all of the opttholind cells. Thore is little variation in alze of these colls. The unfromity in ap-

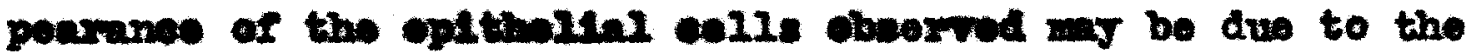
typo or atain eupleged, or to the aseungtien thet the ep1thollal eells ang not pase through a soervters oyelo, but that the socretory action is a contimeves prosess. The oridenes of this experiment abbentiates the experiments of Crown (5) and Beneloy (2), In which the origin of oolletd waterial wa found to be from opttholind colls. Obeorvatiean from alldos were mede in whloh tho oplthollal cell wall bordoring tho follioular eavity was

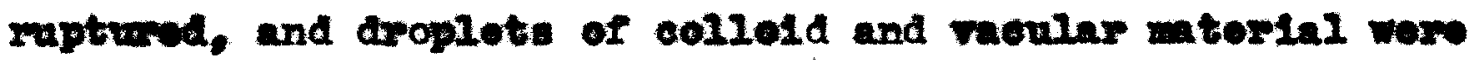
found protorading inte the eavity.

Wias (82), whe pelaved doge and eats with pilcosurpine, found that the blood supply of the throlds from treated anfmals showed an abundant (abnormal) blood auply. In this experiment spoolal attentien was given observatiens concerning the blood supply of both normal 


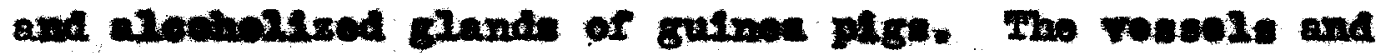
bleod oolls Irou the alcoholised glande prenent the saw appouranes as these from the normin gland (FLowe $\nabla$ and VI). There was no apparent inorease in the cemt of the bleod colls.

The ohang produed in the thorrod elond of cowowos by the rooling of a mat diot as doverribod by

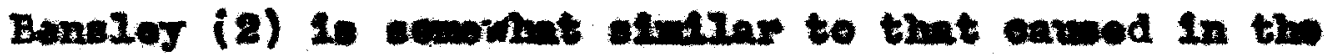
throld gland of guinea pige by the dally adulnatratien

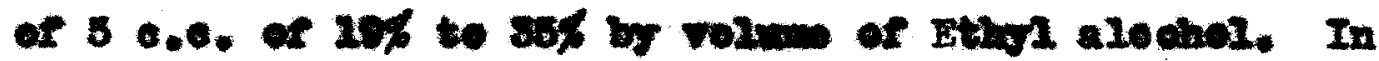
both ences:

$$
\begin{aligned}
& \text { 2. The colvadd wetorial wa inoroased; } \\
& \text { 8. The nenber of varnsles wore inereased, }
\end{aligned}
$$

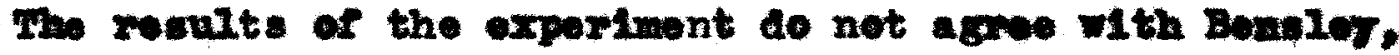
howover, is his aswuptem that the thoreld gland normalis

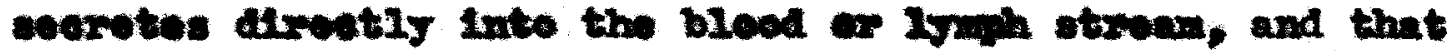
the Indirwet wode is ealy brougint about whon the sate of sedrotilen is to the eneose of bedily noede. The indiroet whed of socretien was the enly wothed of soexution in thie experiment. Obsorvations of slides in beth nexwal

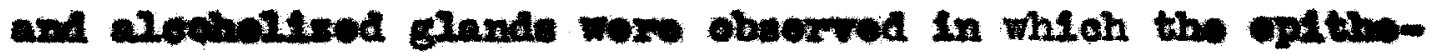
Mer eall wil berdoring the foll1oular onvity wa ruptured and droplote and oolletd and pacular matorlal woro found probruding into the folliaviar arity. Wo groat, detalled hintelogleal study was mat of the genads, but at least no eanes of storilsty wow votad. Arlitt and Wolle (1) roport, howewer, that 
by the adninistration of Ethrs alochol in the food of wie wht rate $\mathrm{fer}$ we or thro waths, that thow orven cecursed complobe aterility. In thin experimont,

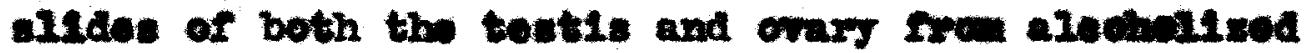
andmala appoarva normal.

The rindinge of this exporiment do not agree

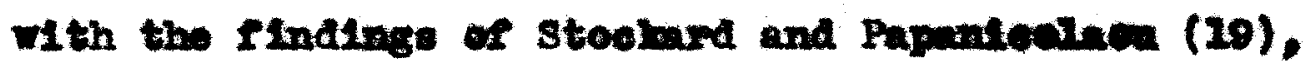

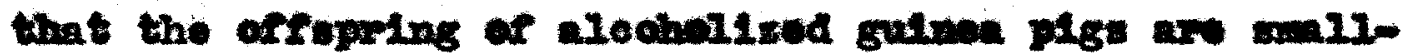
or and reduced in wubor. It wa round that:

1. The averuge mober of ofrapring frum alecholized parents were the was as that Iren contras purontes

2. The averabe weight of the joung smem alecholled parent we 00 gram, when 1s the wawe as the arorage welght of the roung from nowinal parents.

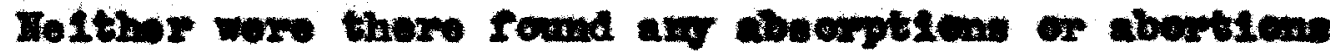
of abryes in alechexlzod nothore. This wa a froguent

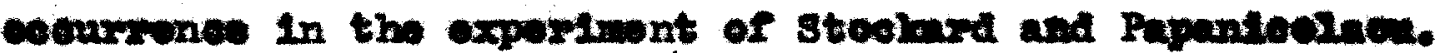
Althorgh sollmam (28) fowad that the cen-

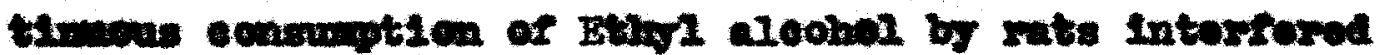

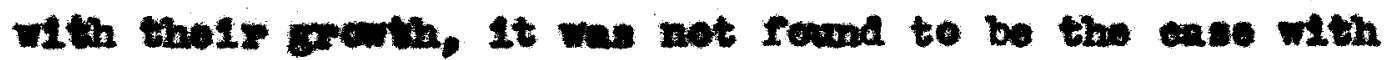
sulnoe pigs, as is hown in table on of this exporimont. Tho tablo thome thet alcohal has no ofrect ca inorease in wolght and that wolght cannot bo used as a orterien for the general effects of aleohol on gainea pigs. 


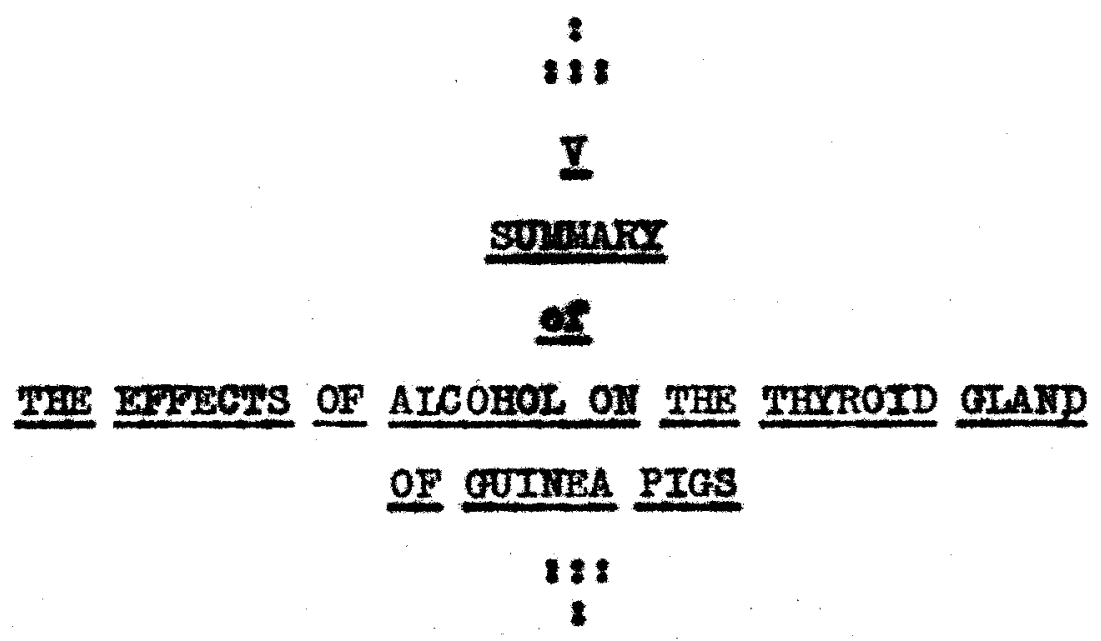


1. The purpose of the study was to obeorve the general effect of aleohal on the boty of the cenven

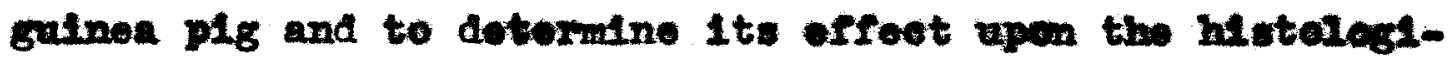
eal strueture of the thryesd gland.

2. The infly adulnistration of 50.0, or 35\% by relene of Ethri alcohol was found to produes tho cosive intexiention on the exporimontal antmals. This troatinont was woed on olght antmals for 200 days,

3. The general efreets of $5,0.0$, of $35 \%$ Ethy alcahol upen the troated animals wore:

2. A Inek of maseviar coordinaticas

2. slight aelsures of anoesing and coughings

3. Watory disoharges from the meuth and nose curling the riret 20 cays of twotraonts

4. A glaser conditien of the oges;

5. Dofoets in roactions.

4. Tho throtd glands Srom both exporimontal and control animal. were obtained at autopy hold imodiately arter the animala wowe rilled. Sectiens wore mas, and the seotions frem experimental animals were compared with those from control antwale:

1. The formelos of the thyrold gland tren exporimontal animals are slightIf Iarger than those from control animals: 
2. Tho follioular eptinellal oolls axo axighty wavem

3. De orteplas of thos follteviar cells ha obenged Srem a gramine apgeranes to a highy vavasiated cenditien. Tho quantity of ogteplawe has boen slightly

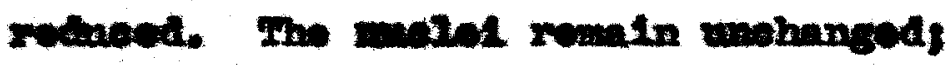

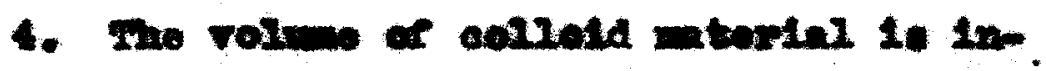
exaned and It contraine wore vapolos. It atain: 14gutor, and in a mority or

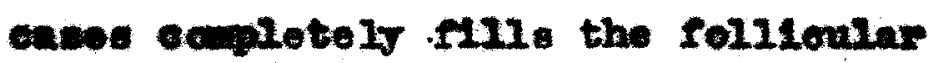
eavity

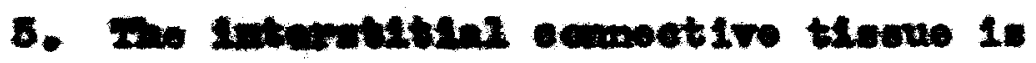
brpieal in rox but greater in gantitys

6. Doquenated and dogonomted ealle appear mere orten in gland: Imen aleom nered antmals.

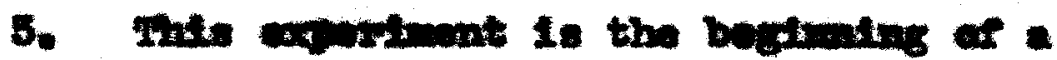

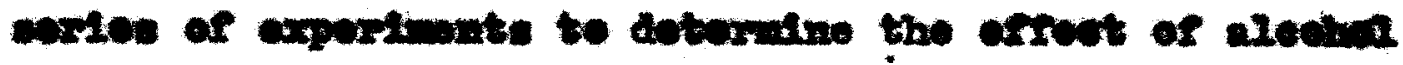

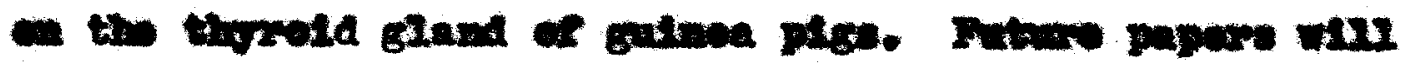

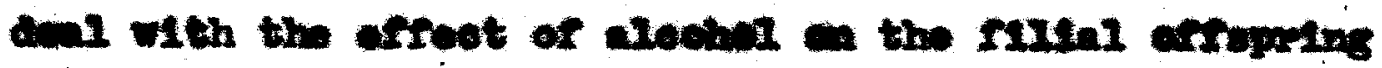
of ponot anting. 
51

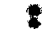

18

BIALTOGRAPEI

18

8 
1. Arlttt, A. H., and WoIIs, H, G. Tho exteet of aleohol on the reproduct170 s10swe. Jour. Exp. Hod, $86,769$. 1017.

2. Bensigs, R. R. Toumal mode of secretion in the thyreld gind. An. Jow. Anat. 19, 57-68. 1926.

3. Condry. E. V. Rotloular anterial in thareid oelle. Ax. Jowr. Anat. 80, 28-39, 1928.

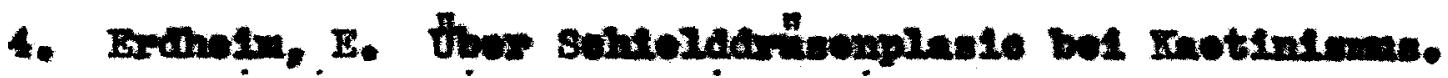
Beltre s. Path, 25, 806, 1014.

5. Falta, W. Budewrine discaces. Trwa, by Hrers, H.

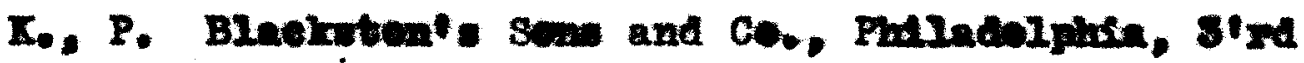
cattien, 1926.

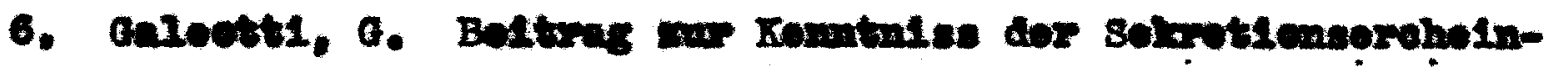

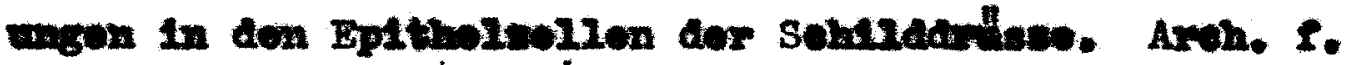
Anat. 48; 505-380,30\%.

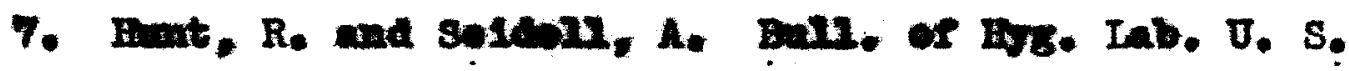
Foalth and War. How. Sorv., Wath. D. C. 47/ 1008.

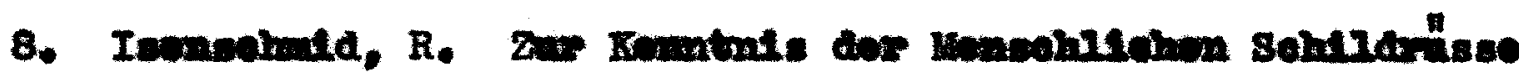

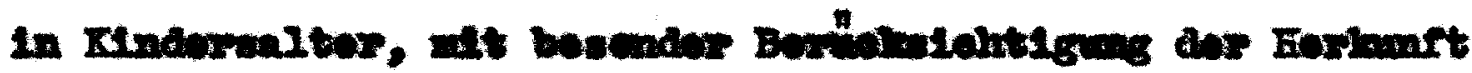

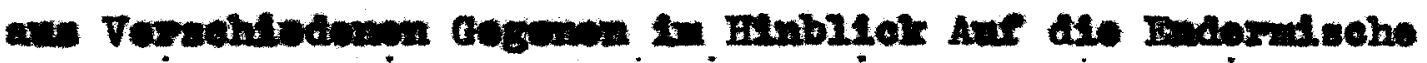
Strwin. Franie. Zoltwabe. I. Path, 5: 4-10. 1010.

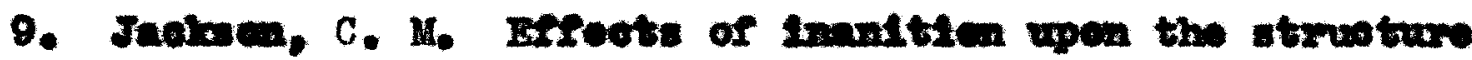
of the thyrold and paratigretd glande of the albino rat. An. Joar: Anat. 19, 306-306. 1916.

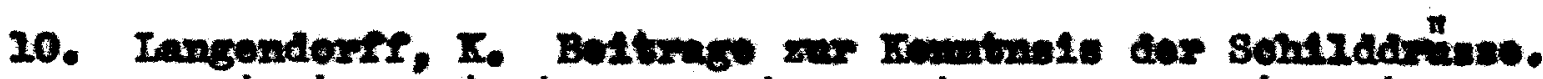
Aroh. F. Annt. W. Physiel. Aboth, 24: 219-248.1694. 


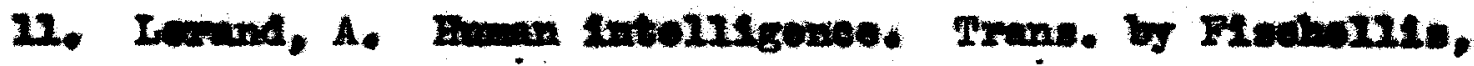
F. A. Davis Co. Philnatpita, 2007.

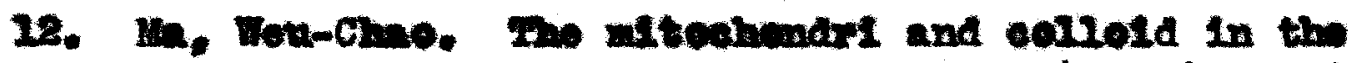
worold glend of the adut alming rat. An. Jow. Ant. 35: 200-221.2025.

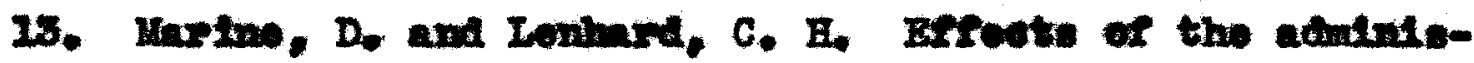

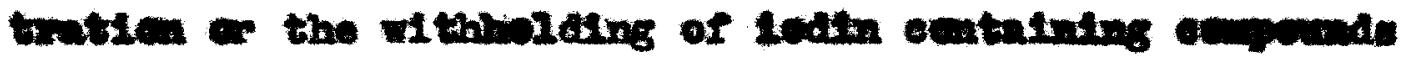

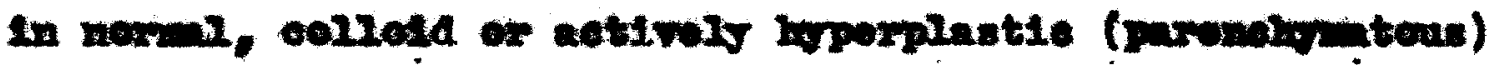

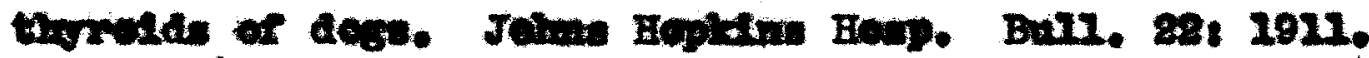

14. Pourl, R. The exprelmontal modifleation of gorre colls. The exteet upon the domestie fond of the ally imaintien - Ethl alookn and cortain related aubataneos. Jour.

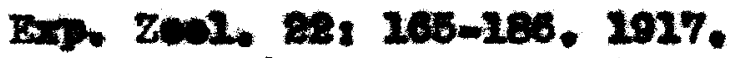

15. Rabavio, s, and Da Cesta, A, C. Sur Ies medifteatien do

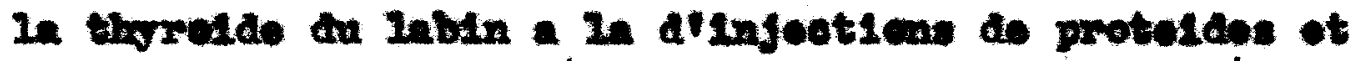

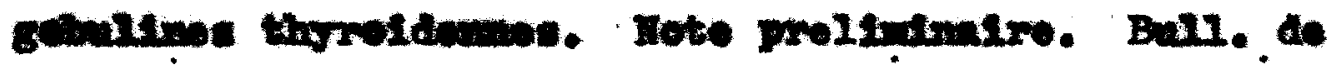

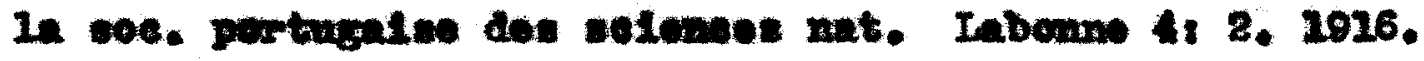

16. Rlehter, C. P. A stuty of the afroet of madrate doses of alookd and the growth and behavier of the rat. Jour. Ix, 2001. 4: 897-418, 1926 .

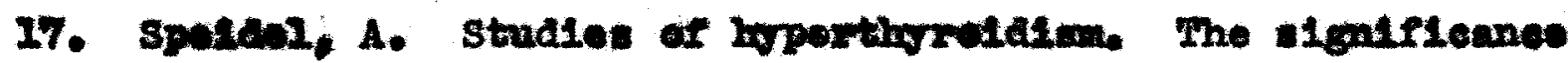

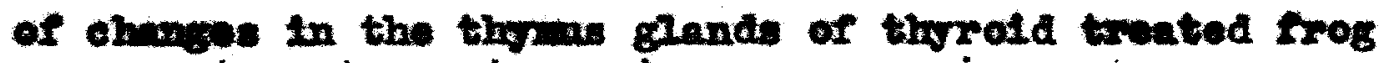
tadpoles. An, Jour. Anat. 37, 141-152, 1986.

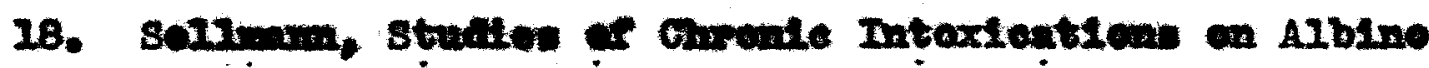
Rate. Joar. Fhara, 16, 291-809,1980. 


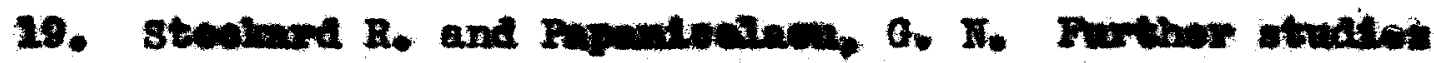

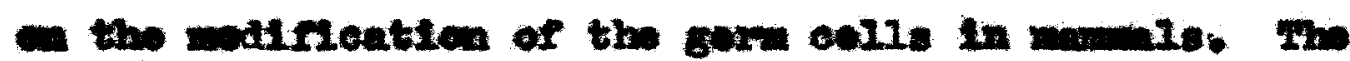

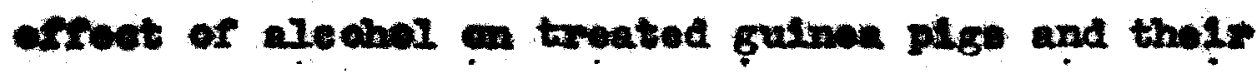

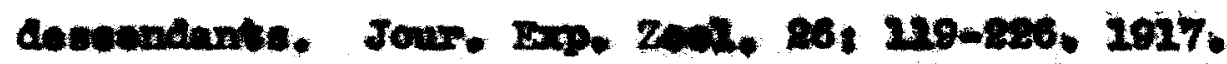

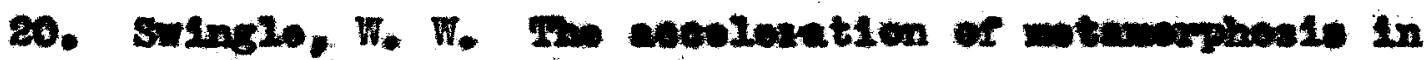

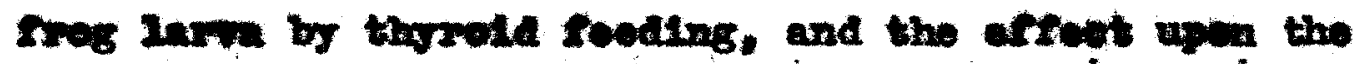

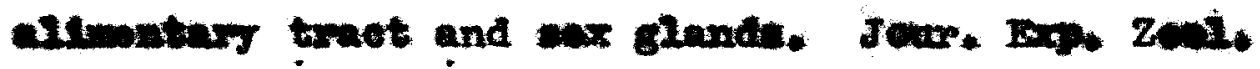

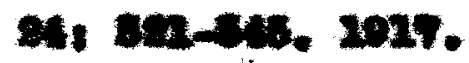

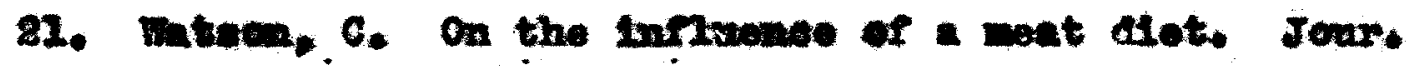
Findal. 20, 10. 2007.

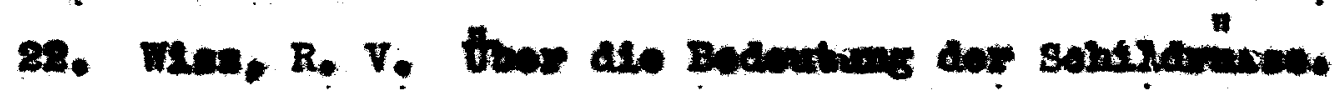

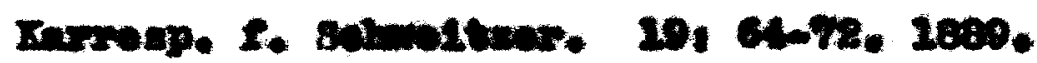

